University of Louisville

ThinkIR: The University of Louisville's Institutional Repository

Electronic Theses and Dissertations

$8-2010$

\title{
Small farmers, slavery, and the political economy of Kentucky's Green River, 1790-1850.
}

Christopher P. Petzold 1982-

University of Louisville

Follow this and additional works at: https://ir.library.louisville.edu/etd

\section{Recommended Citation}

Petzold, Christopher P. 1982-, "Small farmers, slavery, and the political economy of Kentucky's Green River, 1790-1850." (2010). Electronic Theses and Dissertations. Paper 1123.

https://doi.org/10.18297/etd/1123

This Master's Thesis is brought to you for free and open access by ThinkIR: The University of Louisville's Institutional Repository. It has been accepted for inclusion in Electronic Theses and Dissertations by an authorized administrator of ThinkIR: The University of Louisville's Institutional Repository. This title appears here courtesy of the author, who has retained all other copyrights. For more information, please contact thinkir@louisville.edu. 


\title{
SMALL FARMERS, SLAVERY, AND THE POLITICAL ECONOMY OF KENTUCKY'S GREEN RIVER, 1790-1850
}

\author{
By \\ Christopher P. Petzold \\ B.A., University of Louisville, 2006

\begin{abstract}
A Thesis
Submitted to the Faculty of the College of Arts and Sciences of the University of Louisville in Partial Fulfillment of the Requirements for the Degree of
\end{abstract} \\ Master of Arts \\ Department of History \\ University of Louisville \\ Louisville, KY
}

August 2010 
Copyright 2010 by Christopher P. Petzold

All Rights Reserved 


\section{SMALL FARMERS, SLAVERY, AND THE POLITICAL ECONOMY OF KENTUCKY'S GREEN RIVER, 1790-1850 \\ By}

Christopher P. Petzold

B.A., University of Louisville, 2006

A Thesis Approved on

May 26, 2010

By the following Thests Committee:

Dr. A. Glenn Crơhers, Thesrs Diretor and Assistant Professor of History

Dr. Jon Hill Rieger, Professor of Sociotogy

Dr. Thomas C. Mackey, Professor of History 


\section{DEDICATION}

This thesis is dedicated to my grandparents

Mr. Garland Eugene Johnson

and

Mrs. Mary Joyce Johnson

who have given me invaluable educational opportunities

and a lifetime of wisdom and support. 


\author{
ABSTRACT \\ A STUDY OF THE GREEN RIVER'S ECONOMIC AND POLITICAL \\ DEVELOPMENT, 1790-1850 \\ Christopher P. Petzold
}

August 9, 2010

This study focuses on the expansion of the Green River's economic and political importance within Kentucky and how it impacted small farmers of the region. It challenges the idea that small farmers played an insignificant role in the agriculture and industry of the antebellum South. Qualitative data, including journals and letters, are used to understand small farmers' reactions to market expansion. Quantitative data, including agricultural and population censuses, are used to determine small farmers' participation in the economy. Small farmers actively participated in commercial exchanges of crops and livestock and encouraged the growth of a transportation infrastructure to market their goods. Economic development within the region revolutionized activity within the political arena. As the economic infrastructure matured, small farmers elected politicians who sought to expand commerce and safeguard markets. 


\section{TABLE OF CONTENTS}

PAGE

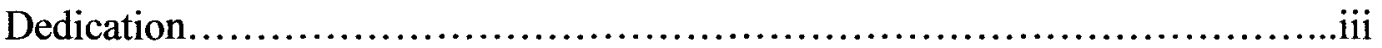

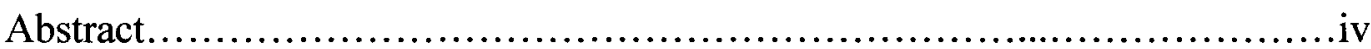

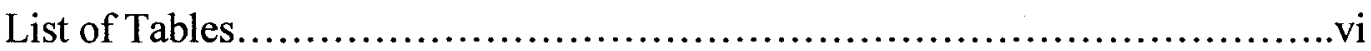

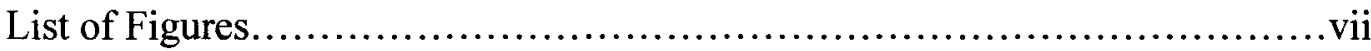

Introduction.........................................................................

Chapter One................................................................. 15

Producing for Independence: Small Farmers and Slavery in Kentucky's Green River

Chapter Two

Politics and the Rise of Green River's Market Economy 1800-1820

Chapter Three

Transformation of the Green River: Banking, Politics, and Internal

Improvements 1820-1850

Conclusion

References.

Appendix.

107

Curriculum Vitae. 


\section{LIST OF TABLES}

TABLE

PAGE

1. Green River Total Population............................................... 107

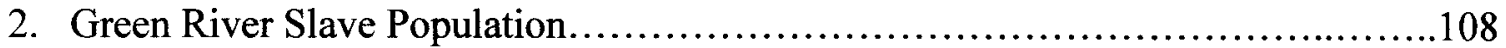

3. Green River Livestock Production.............................................109

4. Green River Crop Production...................................................110 


\section{LIST OF FIGURES}

1. Early Map of the Green River................................................

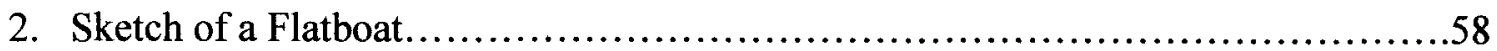

3. The Expansion of United States Tobacco Production by State, $1839-1859 \ldots \ldots \ldots \ldots . . .86$

4. Statement of Tolls Received from Boats on Green and Barren River, 1846..........89 


\section{INTRODUCTION}

The popular image of the Old South consists of sprawling plantations worked by dozens of slaves. Yet this picturesque image hides the existence of a class of minor landholders whom historians often overlook, even though they played a critical role in the Old South. This class of small landholders, known as yeomen farmers or the "plain folk" of the South, worked on small plots of land to provide for their families. They were ambitious, always searching for opportunities to improve their station in life. In the antebellum South, white men obtained independence was by accumulating land and slaves. Land ownership was symbolic of independence for farmers because it provided the means for economic and political liberty. Holding land qualified white males for citizenship, established them as part of a privileged community, and entitled them to vote, among other liberties. Land also enabled small farmers to earn a living and move up in society by selling what crops they produced. When the Revolutionary War ended and settlers could more easily move beyond the Appalachian Mountains, many families headed west in the pursuit of land. Kentucky was one destination for many white families.

Kentucky gained a reputation among settlers for its abundance of wild game and fertile land for farming. Small farmers viewed the region as a land of opportunity and eagerly pushed west over the Cumberland Gap and down the Ohio River into the new territory during the 1770 s and 1780 s. In Kentucky, they hoped for a new 
beginning and to secure economic independence for themselves and their families. Families and even entire communities migrated together. They migrated from other slaveholding states such as Virginia and Georgia, bringing their slaves with them. ${ }^{1}$ One observer, upon seeing a wagon train heading to Kentucky, recorded the zealous spirit among them: "They seemed absolutely infatuated by something like the old crusading spirit to the holy land." Others described Kentucky as the "Eden of the West." Settlers envisioned Kentucky as the land of opportunity where they could settle their families and build their future. $^{2}$

Unfortunately, Kentucky did not become the final destination for most settlers as they hoped. Land became more difficult to obtain as the surge of settlers fought over it. To complicate matters, boundaries of land claims were often vaguely defined. Overlapping boundaries and illegitimate land claims resulted in constant conflict and legal disputes. One of Kentucky's more prominent settlers, Daniel Boone, lost a great deal of land in law suits because of vague land claims. A surveyor once described one of his claims as: "on the waters of licking river including a small spring on the north east side of a small branch ... and some bushes cut down at the same about 20 miles from Boonesborough."3 Legal battles over land ensued as settlers used the territorial and later state court system to try and protect their investments. One Kentucky land owner remarked that one "who buys land there, buys a lawsuit." Lawsuits could ruin settlers who could not afford a lawyer to defend their claims. One settler noted that to "prosecute

\footnotetext{
${ }^{1}$ Lowell H. Harrison and James C. Klotter, A New History of Kentucky (Lexington: University Press of Kentucky, 1997), 49.

${ }^{2}$ Stephen Aron, How the West Was Lost: The Transformation of Kentucky from Daniel Boone to Henry Clay (Baltimore: The Johns Hopkins University Press, 1996), 72.

${ }^{3}$ Ibid., 72.

${ }^{4}$ Harrison and Klotter, A New History of Kentucky, 54.
} 
our claim the last cow and horse must be sold to maintain the suit." ${ }^{\text {"5 }}$ Land speculators' interest in Kentucky further compounded settlers' problems. Absentee speculators employed agents backed with large amounts of capital to acquire as much land as possible. These opportunists used the legal system to take advantage of settlers unfamiliar with the courts. Rather than become embroiled in costly lawsuits, many settlers chose to pack up and seek land elsewhere.

In the face of these disputes, one section of Kentucky remained a region of small farmers. The Green River region in southern Kentucky developed a reputation as a small farmers' paradise because of the availability of land and the ease with which settlers could acquire it. Located in south-central Kentucky, the Green River country stretches from south of the Green River to the Tennessee border. The Tennessee River encloses it on the west and the Cumberland River on the east. The availability of land and the ease with which settlers established themselves in the region was unique in Kentucky. Unlike the Blue Grass, with its sprawling plantations and planter aristocracy, small farmers dominated the Green River region. The settling of the region by yeomen farmers provides historians a rare opportunity to study this group in microcosm.

\footnotetext{
${ }^{5}$ Ibid., 85.
} 
Figure 1: $\quad$ Early Map of the Green River County

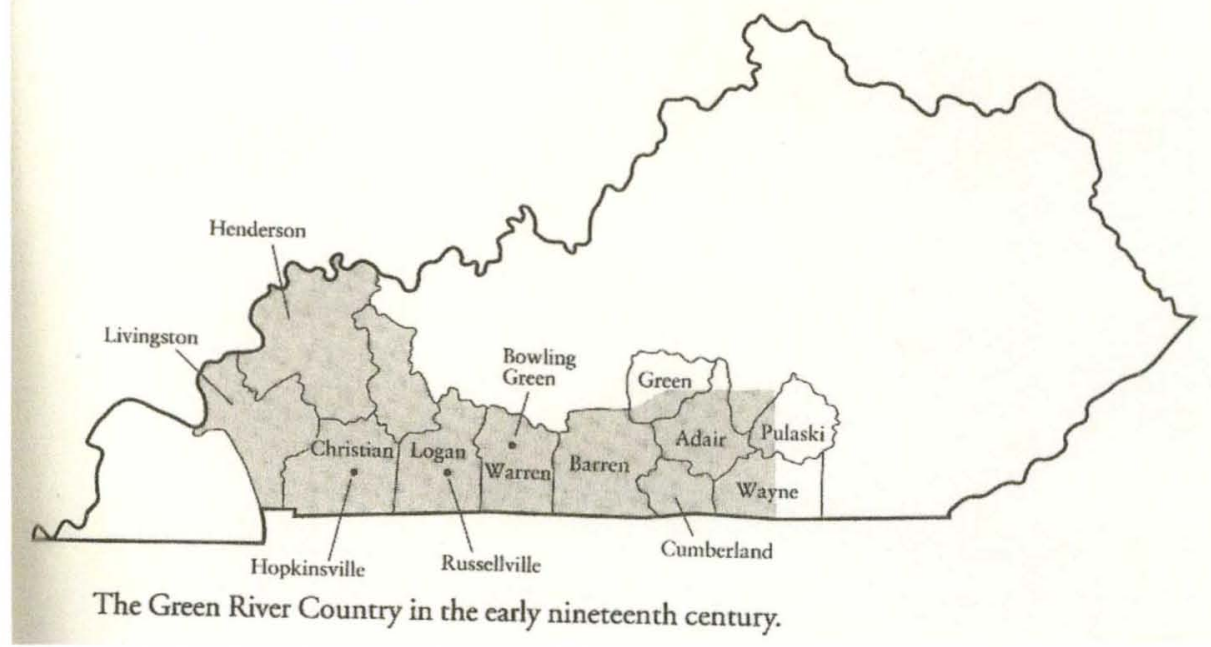

Source: Steven Aron, How the West was Lost, 165.

The region's development occurred in three stages between first settlement in the 1780s and the Civil War: Initial settlement, the rise in the region's political influence, and the gradual transformation of the region from small farms to plantations. During the settlement stage, Revolutionary War veterans and squatters moved in and established small homesteads and grew subsistence crops. By the $1800 \mathrm{~s}$, thousands of additional squatters arrived seeking land. But the surge of settlers led to conflict with speculators who attempted to amass land for profit, and violence over land ownership erupted. The Kentucky legislature sided with settlers in the debate and under the Green River Settlement Act of 1795 allowed squatters to claim up to two hundred acres of land. ${ }^{6}$ In the $1800 \mathrm{~s}$, yeomen landholders dominated the region and their political influence grew. The "Green River Band" challenged the aristocratic Bluegrass planters who controlled Kentucky politics. Green River Democrats passed legislation that favored small farmers

${ }^{6}$ Aron, How the West Was Lost, 153. 
and helped "democratize" Kentucky's government. But small farmers began to abandon the party after 1805 when they supported legislation to expand banking in the Green River. Using capital provided by banks, local merchants petitioned county governments to clear the region's rivers and facilitate access to markets. Farmers embraced improvements in river transportation and they became integrated into the market economy. Improvements in river navigation shaped the region's politics. By the 1830s, farmers elected politicians who promised to expand market interaction by investing in canals.

This thesis documents the transformation of the Green River by examining the shift from an economy that produced subsistence crops to one reliant on slave labor like the Bluegrass. It explores how the yeomen and their families understood this transition and how these changes affected their lives and livelihoods. The commercialization of Green River society had a significant impact on them. Examining the primary sources from the region reveals how the transition affected small farmers. The thesis's three chapters explore the social, political, and economic changes shaping the region between 1790 and 1850 . The first chapter examines the region's settlement by small farmers with an emphasis on their relationship to slavery and its growing importance between 1790 and 1850. The second chapter focuses on the region's political and economic development from 1800 to 1820 . The introduction of banks to the Green River sparked political and economic changes that shaped the wellbeing of small farmers. The third chapter explores further how political and economic changes affected small farmers to 1850. The goal of this thesis is to understand the transformation of the region by 
examining how its small farmers responded to political and economic change and how their participation in the market expanded as their access to it broadened.

The thesis defines yeomen as small farmers who owned their own land and produced goods using family and at times slave labor. The typical farmer owned fifty to two hundred acres of land. ${ }^{7}$ This amount of land allowed a farmer to provide for his family and produce a small surplus for market. Such farmers lacked the capital needed to purchase a sizable slave force or increase their landholdings. Tenants who rented land were not yet yeomen farmers because they lacked economic independence; they did not always have a choice of what crops to grow. ${ }^{8}$ But while historians have a good understanding of what the typical yeoman farmer grew and how much land they owned, understanding their motivations is more difficult. This thesis also focuses on the methods that Green River yeomen employed to sustain their independence and the welfare of future generations. The most common means of maintaining economic independence was using slave labor. Slaves allowed farmers to increase crop production and reap higher market returns. Farmers also used other means to keep wealth in families. Inheritance enabled yeomen to transfer wealth and pass it down to sons and daughters so they could gain independence. By 1820 s, however, passing land down to sons and daughters no longer guaranteed their future. Growing families required more land, and the price rose beyond the means of small farmers. Yeoman had two options: either move out of the Green River country and establish their families elsewhere, or change from subsistence to cash crops and participate more actively in the market.

\footnotetext{
${ }^{7}$ Stephanie McCurry, Masters of Small Worlds: Yeoman Households, Gender Relations, and the Political Culture of the Antebellum South Carolina Low Country (New York: Oxford University Press, 1995), 48-52. ${ }^{8}$ Ibid., 57-58.
} 
One of the main challenges for historians studying small farmers is the scarcity of primary documentation. Unlike slaveholding planters, yeomen left behind few diaries, business ledgers, or letters. The scarce evidence available provides a glimpse into their everyday lives. Planters produced many sources dealing with their businesses, slave problems, families, and day-to-day lives. Sometimes, yeomen business contacts with planters are documented in these sources and help provide a fuller picture of the relationship between yeomen and the larger community. Such indirect sources and quantitative data are often the only means available to study these small landowners and their significance. In order to overcome the lack of primary documentation, some creativity on the part of the historian is necessary. Newspapers are useful to document the economic changes and often reflect small farmers' market participation. Census records are another useful tool for historians. Its quantitative data presents important information on farm size and the relationship of age to land ownership. But it also contains information about farmers' economic activity, particularly agricultural censuses from the late 1830 s to the 1850 s that record type and frequency of crops produced. The Green River was home to a significant Shaker community that left behind useful records. They had religious beliefs different from their yeomen counterparts, but they had many things in common with small farmers. Shakers relied on family labor to produce crops and by the 1830 s participated in the market economy like small farmers.

Southern whites did not have to look far to see examples of dependency in everyday life. Slavery provided a stark lesson to white farmers of the importance of independence. Proponents of slavery argued that the institution was essential to southerners' way of life and provided the foundation of republican virtue. Most 
famously, South Carolinian James Henry Hammond argued this idea in his 1858 "mudsill" speech. "In all social systems," he argued, "there must be a class to do menial duties, to perform the drudgery of life or you will not have the other class which leads progress, civilization, and refinement." In theory, slavery made all white men equal by giving them the means to manage their own labor force. The alternative to slavery, many southerners argued, was wage labor. Southerners believed that slavery removed the conflict between "wage slaves" and capital inherent in a free labor economy and protected individual white competency in the South. ${ }^{10}$

In much of the historiography of the South, historians have failed to devote the same scholarly attention to yeomen farmers as they have to planters and their slaves. While middling farmers comprised most of the South's population, they have been marginalized or treated with contempt. The origins of such beliefs can be traced to travelers' accounts that depicted three classes in the South: planters, poor whites, and slaves. Frederick Law Olmsted's account, written in the 1850s, is typical of such reports about the lives of poor whites. Olmsted, a reporter for the New York Daily Times, agreed to travel the South in the 1850 s to study the effect of slavery on southern society. In the course of his travels, he became fascinated with the lives of ordinary whites. Influenced by his northern upbringing, Olmsted criticized southern culture and manners. He described southerners' houses as "mere hovels, such as none but a poor farmer would house his cattle in the North." He believed southerners' attitudes and ethics little better.

\footnotetext{
${ }^{9}$ Hammond, quoted in, Steve Hahn, The Roots of Southern Populism: Yeoman Farmers and the Transformation of the Georgia Upcountry, 1850-1890 (New York: Oxford University Press, 2006), 88. ${ }^{10}$ James Oakes, The Ruling Race: A History of American Slaveholders (New York: W. W. Norton \& Company, 1998), 123-50. See also Steven Hahn, Roots of Southern Populism, 86-116; and J. William Harris, Plain Folk and Gentry in a Slave Society: White Liberty and Black Slavery in Augusta's Hinterlands (Baton Rouge: Louisiana State University Press, 1985), 15-40.
} 
They "work little and work badly," Olmsted wrote, "earn little, sell little, buy little, and have very little of the common comforts and consolations of civilized life. The destitution is not material only; it is intellectual and moral." To Olmsted, and many northerners who read and wrote similar accounts, southern whites were deficient in every way compared to their northern counterparts. ${ }^{11}$

Some southerners attempted to dispel the myth of a backward southern society and demonstrate its diversity. In 1860, Daniel R. Hundley argued that eight social classes existed in the South from southern gentlemen on top to slaves on the bottom. Hundley believed poor white trash comprised a minority of southern whites; most were middle class. He also argued they were politically active and enjoyed significant political representation. However, Hundley's attempts to correct the stereotype of southern whites met with little success. Tensions between the North and South dampened interest in Hundley's work and it was overlooked as war loomed. ${ }^{12}$ Olmsted's view of southern society prevailed up to the 1940 s. Historian William E. Dodd characterized southern farmers as "the inarticulate masses" who were ignorant but "willing hangers-on of a system which, if they but knew it, could give them no promise of better things."13 Similarly, W. J. Cash argued that small farmers were victims of planters and the cotton economy that pushed their pursuit of land to the periphery where they remained in a state

\footnotetext{
${ }^{11}$ Frederick L. Olmsted, A Journey in the Back Country. (1860; New York: Shocken, 1970), 237, 297- 99.

${ }^{12}$ Daniel R. Hundley, Social Relations in our Southern States (New York: H. B. Price, 1860). See also William J. Cooper Jr., "Daniel R. Hundley: Interpreter of the Antebellum South," in Social Relations in the Old South by Daniel R. Hundley (Baton Rouge: Louisiana State University Press, 1979); Samuel C. Hyde, Jr., "Plain Folk Yeomanry in the Antebellum South," in A Companion to the American South, ed. John B. Boles (Malden, MA: Blackwell, 2002), 141; and Lewis C. Gray, History of Agriculture in the Southern United States to 1860, 2 vols. (New York: Peter Smith, 1941), 1:481-507. Like Hundley, Gray argued that most southern whites were democratic and respectable yeomen. He divided southern society into ten groups from wealthy planters to poor whites.

${ }^{13}$ William E. Dodd, The Cotton Kingdom: A Chronicle of the Old South (New Haven: Yale University Press, 1921), 30-2; and Ulrich Bonnell Phillips, Life and Labor in the Old South (1929; Boston: Little \& Brown, 1963).
} 
of idleness and insignificance. ${ }^{14}$ Historian Samuel C. Hyde Jr. notes the lack of research on yeomen has placed historians in the unusual position of "knowing more about the bondsmen than many of their masters." 15

In the 1940s, Frank Owsley successfully challenged Olmsted's long standing description of the South's plain folk and demonstrated that they played an important role in shaping the history of the antebellum South. Owsley examined the yeomen class in his influential book Plain Folk of the Old South. He argued that the travelers' accounts historians had typically used to understand yeomen were inadequate because northern visitors did not comprehend how yeomen lived. Travelers who described yeomen as idle, he claimed, failed to understand that they raised livestock that required little care most of the time. Moreover, yeomen did not improve their houses and barns, making them appear shoddy to Olmsted, because the South did not have the North's extreme winters and the same need for maintenance. Owsley's arguments exaggerated some aspects of yeomen life, particularly his argument that they were primarily herders rather than farmers. Nevertheless, his insight and persistence in challenging the traditional view of small farmers changed historians' understanding of yeomen, and forced them to reexamine the historical record to uncover their significance. ${ }^{16}$

\footnotetext{
${ }^{14}$ W. J. Cash, The Mind of the South (1940; New York: Vintage Books, 1969), 23-24.

${ }^{15}$ Hyde, "Plain Folk Yeomanry in the Antebellum South," 139.

${ }^{16}$ Frank L. Owsley, Plain Folk of the Old South (1949; Baton Rouge: Louisiana State University Press, 2008), 1-22. Many historians have since revisited the significance of Owsley's work and elaborated on the yeoman farmers' relationship to slavery and network of kinship ties. For a collection of essays related to Owsley's work, see Hyde's Plain Folk of the South Revisited (Baton Rouge: Louisiana State University Press, 1997); also see Walter Kirk Wood, "Before Republicanism: Frank Lawrence Owsley and the Search for Southern Identity, 1865-1965," Southern Studies: An Interdisciplinary Journal of the South 6 (Oct. 1995), 65-77; and Ricky L. Sherrod, "Plain Folk, Planters, and the Complexities of Southern Society: Kinship Ties, in Nineteenth-Century Northwest Louisiana and Northeast Texas," Southwestern Historical Quarterly 112 (July 2009), 1-31. Owsley's work has also compelled a reexamination of northern and southern yeoman culture. For an overview of northern yeoman's idea of economic success and its changing meaning, see Rex Burns, Success in America: The Yeoman Dream and the Industrial Revolution (Amherst: University of Massachusetts Press, 1976), 51-87. For a comparison of northern and southern
} 
Subsequent scholarship has enhanced historians' understanding of the lives of southern whites. Examination of the lives of small farmers throughout the South has revealed their social significance and broadened historians' understanding of other events. Steven Hahn's study of Georgia's upcountry yeomen before and after the Civil War reveals their contribution to larger events. Racked by debt, dependence, and dislocation after the Civil War, Hahn explains why the South's small farmers rallied to the Populist movement following the war. ${ }^{17}$ Other historians focus on regional problems. J. William Harris examines Georgia's upcountry yeomen to understand the social interactions between yeomen, planters, and their slaves. ${ }^{18}$ Women historians have also broadened our understanding of small farmers by reinterpreting the historical evidence in various ways. Stephanie McCurry considers the gender divisions and power relations within small farmers' households and how these structures helped maintain the economic independence of yeomen. $^{19}$

Perhaps the biggest question posed by historians who study southern yeomen is their economic significance and market participation. ${ }^{20}$ Marxist historian Eugene

yeoman ideals, see Louis Billington and David Brown, "Yeomen and Yankees Across the Mason-Dixon Line: A Different Perspective on the Antebellum North/South Divide?" European Contributions to American Studies 58 (Aug. 2004), 101-16.

${ }^{17}$ Hahn, Roots of Southern Populism. See also Mark V. Wetherington, Plain Folk's Fight: The Civil War and Reconstruction in Piney Woods Georgia (Chapel Hill: University of North Carolina Press, 2005); and The New South Comes to Wiregrass Georgia, 1860- 1910 (Knoxville: University of Tennessee Press, 1994).

${ }^{18}$ Harris, Plain Folk and Gentry, 1-7.

${ }^{19}$ McCurry, Masters of Small Worlds. For a similar discussion about the colonial South, see Kathleen M. Brown, Good Wives, Nasty Wenches, and Anxious Patriarchs: Gender, Race, and Power in Colonial Virginia (Chapel Hill: University of North Carolina Press, 1996).

${ }^{20}$ A rich historiography about the socioeconomics of southern whites has resulted from this debate. On the development of land ownership and agrarian ideals, see Steven Sarson, "Yeoman Farmers in a Planters' Republic: Socioeconomic Conditions and Relations in Early National Prince George's County, Maryland," Journal of the Early Republic 29 (Spring 2009), 63-99. Related to this discussion is the role of banks in fostering economic development. For an overview, see Donald R. Adams, "The Role of Banks in the Economic Development of the Old West," Essays in Nineteenth Century Economic History: The Old Northwest, eds. David C. Klingaman and Richard K. Vedder (Athens: Ohio University Press, 1975), 20845; Hugh T. Rockoff, "Varieties of Banking and Regional Economic Development in the United States, 
Genovese has deeply influenced the historiography on this issue. Like Olmsted,

Genovese asserts that southern society was dominated by "the hegemony of the slaveholders, presupposing the social and economic preponderance of the great slave plantations." He denies the existence of an independent yeomanry. "The concentration of landholding and slaveholding," Genovese argues, "prevented the rise of a prosperous yeomanry and of urban centers." Genovese dismisses the economic significance of yeomen and asserts that they did not want to "exchange their proud isolation and regional way of life for integration into the commercialized economy." So long as the market did not penetrate upcountry communities and threaten to undermine local autonomy, Genovese contends, planters could legitimately claim to protect small farmers' interests and control the levers of political and social power. ${ }^{21}$

Other historians have offered more nuanced explanations of small farmers' market activity. James Oakes asserts that the South was capitalistic and small farmers entered the market to acquire wealth and emulate planters' success. ${ }^{22}$ Daniel Vickers also argues that small farmers were capitalistic but he believes they were motivated by the idea of economic independence or "competency." Vickers defines competency as "possessing sufficient property to absorb the labors of a given family while providing it

1840-1860," Journal of Economic History 35 (Mar. 1975), 160-81; A. Glenn Crothers, "Banks and Economic Development in Post-Revolutionary Northern Virginia, 1790-1812," The Business History Review 73 (Spring 1999), 1-39.; and Robert E. Wright, "Banking and Politics in New York, 1784-1829" (Ph.D. diss., State University of New York at Buffalo, 1997). For a discussion of economic development in the slave South, see Gavin Wright, The Political Economy of the Cotton South (New York: W. W. Norton, 1978); and Robert L. Fogel and Stanley L. Engerman, Time on the Cross: The Economics of American Negro Slavery (Boston: Little, Brown and Company, 1974).

${ }^{21}$ Eugene D. Genovese, The Political Economy of Slavery: Studies in the Economy and Society of the Slave South, $2^{\text {nd }}$ ed. (1965; Hanover, N.H.: Wesleyan, 1989), 13; and "Yeomen Farmers in a Slaveholders' Democracy," Agricultural History 49 (Apr. 1975). 335-36. For similar arguments, see McCurry, Masters of Small Worlds; and Steven Hahn, The Roots of Southern Populism.

${ }^{22}$ Oakes, The Ruling Race, 57. For a view of northern yeomen, see Thomas S. Wermuth, "'To Market, To Market': Yeoman Farmers, Merchant Capitalists and the Development of Capitalism in the Hudson River Valley, 1760-1820," Essays in Economic and Business History 9 (Mar. 1991), 20-34. 
with something more than a mere subsistence." Competency did not mean farmers were independent of the market, but that they entered the market on their own terms and negotiated the exchange of goods with the understanding that they were not bound to the market. Equally important, they sought to produce goods by managing their own labor. "Self-working farmers" produced for themselves and no one directed them about how or what to produce. Independent families directed the labor of their dependants to protect their household independence. To Vickers, "comfortable independence," not wealth, motivated yeomen. ${ }^{23}$

This thesis argues that small farmers' market activity followed a distinct trajectory. Between 1790 to 1810 , Green River's small farmers decisions adhered more closely to Vickers's model of economic behavior. What little interaction they had with the market was used to maintain economic independence. In the $1820 \mathrm{~s}$, however, Green River farmers became more capitalistic, they embraced improvements in transportation and market access. By the 1840 s, they had become fully integrated into the market economy, produced large quantities of staple crops like tobacco, and elected politicians that promised to protect access to market.

Kentucky's Green River yeomen farmers occupy a special place in Kentucky's history. This region of Kentucky was uniquely "yeomen" in that small farmers could easily obtain land on which to settle. Through hard work, diligence, and perseverance small farmers carved a niche for themselves and their families on the frontier. But as

\footnotetext{
${ }^{23}$ Daniel Vickers, "Competency and Competition: Economic Culture in Early America," The William and Mary Quarterly, $3^{\text {rd }}$ Series, 47 (Jan. 1990), 3. Also see Allan Kulikoff, "The Transition to Capitalism in Early America," $3^{\text {rd }}$ Series, 46 (Jan. 1989), 120-44; James A. Henretta, "Families and Farms: Mentalite in Pre-Industrial America," The William and Mary Quarterly, 3rd Series, 35 (Jan. 1978), 3-32; and Christopher Clark, "Household Economy, Market Exchange and the Rise of Capitalism in the Connecticut Valley, 1800-1860," Journal of Social History 2 (Winter, 1979), 169-89.
} 
time passed, life changed for small farmers. As commercial opportunities expanded, the means of achieving economic independence changed. Instead of producing enough crops to sustain their family, small farmers became integrated into the market. This thesis examines the economic and political consequences of the expanding market economy within the Green River. The focus is on small farmers and how they lived, understood, and survived this change. By telling their story in Kentucky, it also tells the story of that overlooked class throughout the South-yeomen farmers. 


\section{CHAPTER ONE}

\section{PRODUCING FOR INDEPENDENCE: SMALL FARMERS AND SLAVERY}

\section{IN KENTUCKY'S GREEN RIVER}

Frederick Jackson Turner once wrote that the settlement of the west was "the contest between the capitalist and the democratic pioneer." Turner's statement rings true for Kentucky. From the region's first settlement in the 1780s, small farmers' seeking land to support their families clashed with land speculators eager to resell land for a profit. By the $1800 \mathrm{~s}$, political and social forces combined to make the Green River region of Kentucky a unique political entity. The absence of large speculators, equal distribution of land, and the quality of the land itself made it one of the best "poor man's" countries. To small farmers, the Green River represented a place where they could acquire land and provide for the future of their children. Though the region became known for its fertility, that was not what attracted its earliest settlers. According to one yeoman farmer, the ability to "give each of his children a sufficient portion" allowed him "a greater degree of happiness than any other situation."2 Speculators' initial interest in the Green River was blunted by the reports of hunters and early settlers more accustomed to the fertility of the Bluegrass than the "prairies" of the region. One settler described the

\footnotetext{
${ }^{1}$ Frederick Jackson Turner, in Stephen Aron, "Pioneers and Profiteers: Land Speculation and the Homestead Ethic in Frontier Kentucky," The Western Historic Quarterly 23 (May 1992), 179.

${ }^{2}$ Ibid.
} 
area as "so sterile and inhospitable that neither beast nor man can reside there."3 Contemporaries described it as a haven for the poor. One contemporary said it was "filled with nothing but hunters, horse thieves and savages where wretchedness, poverty, and sickness will always reign."4

Prospective settlers often heard tales of Kentucky's beautiful and fertile land and abundance of wild game from veterans active in the Ohio Valley during the Seven Years' War. ${ }^{5}$ Many travelers' accounts praised the Green River especially for its beauty as well as its natural advantages for farmers. Emeline Richmond, for example, noted that the land "excites the wonder of us all as we are passing through it." When white settlers arrived, the region was ideal for grazing large numbers of sheep, cattle, and pigs. Baptist preacher David Barrow passed through the region in 1795 and was amazed by its commercial opportunities. He noted the ease with which farmers could access northern and southern markets:

Their rivers are numerous and mostly navigable almost from their sources to their mouths. With the greatest ease to export in vessels all that super abundance that their fat country yields to them over and above what they can possibly consume themselves, would always supply them with plenty of money to answer every purpose they could have a call for.

\footnotetext{
${ }^{3}$ Stephen Aron, How the West Was Lost: The Transformation of Kentucky from Daniel Boone to Henry Clay (Baltimore: The Johns Hopkins University Press, 1996), 151.

${ }^{4}$ Ibid.

${ }^{5}$ Lowell H. Harrison and James C. Klotter, A New History of Kentucky (Lexington: The University Press of Kentucky, 1997), 5.

${ }^{6}$ Emeline Holden Richmond Journal, entry for Oct. 3, 1826, Kentucky Library, Western Kentucky University, Bowling Green, Kentucky (hereafter WKU).
} 
Barrow also noted the region's livestock. The Green River, he observed, "is famous for horses, cattle, sheep, swine, fowls; and near the waters for fish and honeybees."

Many of the first settlers to the region were Revolutionary War veterans. During the war, Virginia lacked the funds to pay soldiers and sought alternate means to raise enlistments. To sustain the war effort, the state offered military veterans land south of Kentucky's Green River. ${ }^{8}$ The number of acres granted to soldiers depended on their rank and length of service, but even the lowest ranking soldiers received two hundred acres, a large enough plot for a small farmer to support his family. Samuel Seay, a Virginian who served as a private in the Revolutionary War, received a grant of two hundred acres south of the Green River. In 1793, Seay and his brother Jacob, also a Revolutionary War veteran, emigrated to Kentucky with their families. ${ }^{9}$ Albrittain Drake was another Virginia soldier who received a land grant and migrated with his family to the Green River in the late 1790s. "I think you have made a verey grate exchange," Michael Collins congratulated Drake on his move to the Green River. "The approaching generation will give you grate credit for your move." For Drake, the move brought significant success. By the time he died in 1832 , he owned nearly ten thousand acres of land and owned a sizable quantity of livestock and five slaves. ${ }^{10}$

Other veterans sought to migrate to Kentucky but could not because of financial or health problems. Captain John Hines wanted to travel west with his family, but could not do so immediately. "I feel an intention to see Kentucky if strength permits," Henry wrote to his son John. "I shall endeavor to get the balance of my family there also."

\footnotetext{
${ }^{7}$ David Barrow Journal, entry for July 10, 1795, WKU.

${ }^{8}$ Harrison and Klotter, A New History of Kentucky, 55.

${ }^{9}$ Samuel Seay Journal, entry for Apr. 2, 1793, WKU.

${ }^{10}$ Michael Collins to Albrittain Drake, Aug. 22, 1809, Drake Family Papers, WKU.
} 
Unable to go himself, Henry sent his son to Kentucky to secure his veteran land claim in the Green River. As a hunter, Hines appreciated the wilderness of Kentucky, but financial considerations also convinced him to strike west. "The ill fate which I have undergone recently [in law suits] has reduced me to straights for money," Hines wrote. He asked his son to "use [his] endeavors to accumulate to me what may be due." Hines finally travelled to Warren County in the Green River in 1810 , where he lived with his thirteen sons and four daughters for a few years before passing away in $1813 .{ }^{11}$

Emigration to Kentucky was full of risks and many veterans of the Revolutionary War sold their land claims to speculators instead. Many found the process of patenting land complicated and time consuming. The trip to Kentucky was dangerous, and frequent Indian raids also made the move financially risky. ${ }^{12}$ Before the American Revolution ended, speculators like Philadelphian Samuel Throckmorton acquired military land claims from veterans, advertised thousands of acres of land in the Green River in newspapers as far north as Pennsylvania, and encouraged small farmers to settle there. Throckmorton offered prospective settlers Green River land "which [has] a rich soil in a country which is likely to be very speedily settled and worth the attention of farmers moving to the frontier." ${ }^{13}$ A few months later, C. Bullitt, another Philadelphia land speculator, advertised that he had over twenty-four thousand acres of "first quality" Green River land for sale that was originally "due for military service." He offered to sell the land in three annual payments. ${ }^{14}$ "WANTED," advertised land speculator John

\footnotetext{
${ }^{11}$ Henry Hines to John Hines, June 20, 1810, Hines Family Papers, WKU.

${ }^{12}$ For a detailed description of this process, see James A. Ramage, "The Green River Pioneers: Squatters, Soldiers, and Speculators," Register of the Kentucky Historical Society 75 (July 1977), 171-90; and Patricia Sue Watlington, "The Kentucky Spirit: Kentucky Politics, 1779-92" (Ph.D. diss., Yale University, 1964), 9-15.

${ }^{13}$ The Pennsylvania Packet, May, 10, 1783.

${ }^{14}$ The Pennsylvania Packet, Sept. 11, 1783.
} 
Moylan, "a few thousand acres of military land warrants, for which the highest price will be given." 15 Speculators drove up the price of land, often beyond the means of small farmers. Settlers greatly resented the speculators, many of whom did not live in Kentucky. ${ }^{16}$ It is difficult to determine how many veterans sold their claims to land speculators, but judging by the quantity of land advertised in newspapers, quite a few did.

Those who risked their lives to resettle in the Green River did not sell out their land so easily once settled. When Robert Triplett, an agent for a land speculation company, arrived in the Green River to purchase more land for his employer, settlers greeted him with hostility. "The occupants," he reported, "refused to surrender the land." Many of the "occupants" who Triplett encountered were not veterans with legitimate claims. The Green River also attracted settlers who desired land but lacked the means to purchase it or did not receive military land claims. These settlers did not have a legal entitlement to the Green River land; rather, they squatted on unoccupied land and based their claims on their occupancy. ${ }^{17}$ Having little money, settlers invoked the "homestead ethic." Hermon Husband, leader of the Regulator movement in North Carolina, argued that squatters had a "kind of right" to "back [country] vacant lands" and that speculators had no legal right to interfere with squatters who moved "out, from the interior parts to the backlands, with their families, and find a spot, whereon they build a hut, and made some improvements."18 As historian James Ramage suggests, many Regulators were farmers of average means who hoped they "would be deeded proprietors by occupancy of

\footnotetext{
${ }^{15}$ [Lexington] Kentucky Gazette, Apr. 21, 1792.

${ }^{16}$ Roy M. Robbins, "Pre-emption-A Frontier Triumph," The Mississippi Valley Historical Review 18 (Dec. 1931), 333.

17 Aron, "Pioneers and Profiteers," 186.

${ }^{18}$ Ibid., 189. See also A. Roger Ekirch, "'A New Government of Liberty': Hermon Husband's Vision of Backcountry North Carolina, 1755," The William and Mary Quarterly, 3rd Series, 34 (Oct. 1977), $632-46$.
} 
at least some valuable tracts." ${ }^{19}$ During the 1780 s and 1790 s, word spread of the "barrens" fertility, and hundreds of new squatters arrived in the region hoping to acquire land.

The population of the Green River grew rapidly. In the 1790 census, the entire population south of the Green River, which was then known as Lincoln County, numbered 6,500 . In the 1800 s and 1810 s, population levels increased dramatically. With six thousand inhabitants, Green County, which had recently been created, had nearly as many people as the entire region in 1790 . Similarly, Barren County and Warren County held nearly 4,700 individuals each. Lincoln County still made up most of the Green River lands and it had the largest population at eight thousand. By 1820 , county populations doubled and in a few counties even tripled in population numbers. The populations of Barren County and Green County grew to ten thousand and twelve thousand, respectively. Warren County almost tripled its population from 4,700 in 1800 to twelve thousand in 1820 (see Table 1). ${ }^{20}$

The influx of settlers, many of whom were squatters, increased speculators' concerns. Squatters who moved on to land claimed by speculators often faced the threat of eviction but they were not intimidated by such threats. At times, violence erupted between the two groups. Disillusioned settlers formed "Regulator" groups that terrorized land agents. They often threatened the speculators with death if they refused to leave and sometimes burned down their homes. Regulators also attacked lawyers they believed used legal trickery to aid the land agents and cheat the settlers out of their land. ${ }^{21}$ The

\footnotetext{
${ }^{19}$ Ramage, "The Green River Pioneers: Squatters, Soldiers, and Speculators," 180.

${ }^{20}$ Statistics for the Total Population of Kentucky Counties 1790-1820, University of Virginia's Online Census Survey, http://mapserver.lib.virginia.edu/.

${ }^{21}$ Aron, How the West Was Lost, 60.
} 
boldest scheme was led by Richard Henderson and his Transylvania Company in 1774 . A judge by profession, Henderson's land speculations in North Carolina made him unpopular and helped provoke the Regulator movement where settlers lashed out at lawyers and speculators whom they believed had cheated them out of their land. In 1774, Henderson established the Transylvania Company with a group of prominent North Carolina entrepreneurs. With settlers moving into the Ohio Valley, they saw an opportunity for profit. The group negotiated directly with the Cherokees who controlled the land rather than go through state land offices. For ten thousand dollars worth of goods, Henderson purchased the territory between the Kentucky and the Cumberland Rivers for the purpose of "settling the country."22

Many contemporaries viewed Henderson and his partners as nothing more than "an infamous company of land pirates." ${ }^{23}$ Fellow speculators feared that Henderson's ownership of huge tracts of land would shut them out of western speculation. "If some effectual stop is not put to these daring usurpations," warned Governor Josiah Martin of North Carolina, "such adventurers will posses themselves soon of all the Indian country." Henderson's scheme fell apart after he refused to include Virginian Governor Patrick Henry in the deal. A disgruntled Henry "roused the attention of a number of people of note" and used his influence with Virginia legislators to invalidate the company. On December 7, 1776, the Virginia Assembly seized the lands Henderson had purchased from the Cherokees. ${ }^{24}$

\footnotetext{
${ }^{22}$ Stephen Aron, How the West Was Lost, 61-64. See also Aron, "Pioneers and Profiteers," 179-98; and Archibald Henderson's "Richard Henderson and the Occupation of Kentucky, 1775" The Mississippi Valley Historical Review 1 (Dec. 1914), 341-63.

${ }^{23}$ Aron, How the West Was Lost, 62.

${ }^{24}$ lbid., 64.
} 
Speculators were not the only ones interested in Green River land. A few individuals amassed land for their own use. Captain Robert Craddock, a soldier turned planter, used his influence and capital after the war to amass fourteen hundred acres in Logan County from veterans who did not redeem their Kentucky claims. He established himself in the Green River as a typical Virginia gentlemen, building a plantation he named "The Hermitage" and purchasing several dozen slaves to work his land. ${ }^{25}$

Squatters lobbied the state for support. The Kentucky legislature sided with the squatters and under the Homestead Act of 1795 decided to sell them the land on which they currently resided at generous terms. The decision of the legislature to favor squatters over speculators gave the Green River the highest percentage of land owners in the state by 1800 . In other parts of Kentucky, only 49.2 percent of households owned land, but in the Green River the number was between 54.3 and 67 percent. ${ }^{26}$ By 1800 , the region was largely populated by farmers who owned two hundred acre farms. In every Green River county, at least half of the residents owned two hundred acres and in some counties almost three quarters of them had holdings this size. ${ }^{27}$

But as tempting as many newcomers found Green River land, the region was not without problems and many moved on after a few years. Lawsuits over land plagued the Green River. As in the rest of Kentucky, vague land boundaries allowed some settlers to cheat the system and attempt to expand their property at the expense of their neighbors. ${ }^{28}$ Property bounded by topographical features like rivers or creeks were more clearly defined and sometimes "protected" settlers from lawsuits over land. But small physical

\footnotetext{
25 "Outstanding Pioneer of County Named," Glascow Times, Mar. 20, 1949, in Robert E. Craddock Family Papers, WKU.

${ }^{26}$ Harrison and Klotter, A New History of Kentucky, 69.

${ }^{27}$ Aron, How the West Was Lost, 153.

${ }^{28}$ Harrison and Klotter, A New History of Kentucky, 53.
} 
features did not always prevent lawsuits. After Jacob Goodman arrived in the Green River in 1820 , he found himself in a lawsuit with his neighbors. Between 1820 and 1826 , Goodman was sued six different times over disputed land boundaries. ${ }^{29}$

The first settlers to the Green River accepted the institution of slavery. The few small farmers who owned slaves brought their bondspeople with them when they migrated to the Green River in the 1780 s and 1790 s. According to the 1790 census, one thousand slaves lived in the Green River. In subsequent years, the enslaved population rose. By 1800 , the slave population had doubled, and in 1810 slaves numbered almost ten thousand. The increase in slaves was particularly rapid in counties that bordered rivers, probably because settlers could use flatboats to reach the areas more easily, which raised the value of land. The population of Henderson County, bordered by several rivers in the western Green River, was 30 percent enslaved in 1810 . By 1820 , slaves constituted 40 percent of the total population of the county. In comparison, only 20 percent of the population of the inland counties of Green, Barren, and Warren was enslaved in 1820. Twenty years later, those counties had doubled their slave population. In Green River towns, the enslaved percentages were higher. In Hopkinsville, slaves composed nearly 40 percent of the population in 1840 (see Table 2 ). ${ }^{30}$

Slave labor enabled farmers to clear land and make it suitable for raising crops. Once a farmer claimed land, he devoted most of his time to clearing and managing it. Corn was an important staple crop for small farmers because it was easy to grow and store, and provided food for the family and livestock. In addition, small farmers and their

\footnotetext{
${ }^{29}$ Receipts from Jacob Goodman, Jan. 29, 1820, Aug. 3, 1826, Goodman Family Papers, WKU.

${ }^{30}$ Marion B. Lucas, A History of Blacks In Kentucky, Volume 1: From Slavery to Segregation, 1760-1891 (Frankfort, Kentucky: The Kentucky Historical Society, 1992), xix-xxi; U.S. Census 1790, University of Virginia, http://mapserver.lib.virginia.edu/.
} 
slaves planted wheat and oats as they cleared more land. Farmers relied heavily on family labor and every member of the household had assigned duties. Sons worked in the fields with their fathers helping to plant crops and learn skills that would benefit them when they owned their own farms. Women and daughters often planted and tended vegetable gardens to supplement the family's diet in addition to raising children and making and mending clothing. ${ }^{31}$ Farmers grew small food surpluses and staples such as tobacco or cotton for market to generate income to purchase manufactured goods they could not produce at home. ${ }^{32}$ Livestock contributed to family support in many ways. As wild game disappeared, hogs became small farmers' main source of meat. Horses and mules enabled farmers to plow more land and raise larger crops. Green River land lent itself to raising and grazing livestock. Slaves helped tend livestock, feeding, rounding up strays, and milking cows.

The writing of Kentucky's 1792 constitution sparked debate over the role of slavery in the state. Slave owners needed accessible markets to sell their slave-produced goods. In contrast to eastern states that bordered the ocean or had a more developed transportation infrastructure, Kentucky farmers were largely isolated from markets. Kentucky's proslavery faction had outspoken advocates. Chief among them was George Nicholas, the "father" of Kentucky's first constitution. Nicholas argued in favor of slavery on political, historical, and Biblical grounds, and believed that the institution improved the lives of free white men. He also contended that abolishing slavery without

\footnotetext{
${ }^{31}$ Stephanie McCurry, Masters of Small Worlds Gender Relations and the Political Culture of the Antebellum South Carolina Low Country (New York: Oxford University Press, 1995), 49, 56.

${ }^{32}$ Harrison and Klotter, A New History of Kentucky, 137.
} 
compensating owners was unjust and impractical because the state could not afford to reimburse every Kentucky slave owner in the state the cost of their slaves. ${ }^{33}$

Other Kentuckians called for an end to slavery. Some recognized the inherent contradiction between the Declaration of Independence, which championed the rights of all men, and the Constitution, which enabled some to hold their fellow human beings in bondage. "Are not our names written in the American Book of Liberty with the precious blood of our fellow citizens who bravely fought and freely bled and suffered death and martyrdom for the grand American life of liberty?" asked one preacher of his Kentucky congregation. "The poor, ignorant African slaves [held] in American bondage whose sanctuary is the grave and whose [only] hope is giving up the ghost, their lot is utterly deplorable. ${ }^{34}$ The Reverend David Rice was the most outspoken critic of slavery at Kentucky's constitutional convention. Rice declared that slavery was incompatible with the teachings of the Bible, unjust to blacks, and harmful to whites. The only solution, Rice argued, was immediate emancipation without compensation for slave owners. $\mathrm{He}$ urged his fellow delegates to amend Kentucky's constitution and abolish slavery. ${ }^{35}$

Some Kentuckians feared the impact slavery had on the whites. Writing under the name "Scaevola," Henry Clay attacked the institution during Kentucky's 1792 constitutional debate. He claimed that slavery hurt both blacks and whites. "It deprives the slave of the best gift of heaven," Clay wrote, and "in the end injures the master too, by laying waste his lands, enabling him to live indolently, and thus contracting all the vices generated by a state of idleness." Clay proposed gradual emancipation, but this was

\footnotetext{
${ }^{33}$ Ibid.

${ }^{34}$ John Shaw to The Venerable and Faithful Ministers of God, June 17, 1793, Filson Historical Society, Louisville, Kentucky (hereafter FHS).

${ }^{35}$ Harrison and Klotter, A New History of Kentucky, 63.
} 
also problematic. Freeing the slaves, proponents of slavery and abolitionists feared, would unleash a wave of retribution by African Americans once held in bondage. Seeing no viable alternatives, most white Kentuckians concluded they must live with this "necessary evil," believing the institution would in the end undo itself. ${ }^{36}$

The vote to protect slavery in Kentucky's constitution was surprisingly close at twenty-six to sixteen. Writing a new constitution in 1799 , the state debated slavery again. In the seven years since 1792, however, the number of the enslaved grew rapidly, some 241 percent. This did not deter antislavery ministers who again led the charge to abolish slavery. But this time, they did not call for the immediate end of the institution. Instead, they tried to implement in the new constitution an article that banned the importation of slaves into the state at a future date. But they failed and Kentucky's 1799 constitution protected slavery. ${ }^{37}$

Little evidence suggests that Green River residents opposed slavery. As much as some farmers wanted to distance themselves from the institution, they recognized its economic benefits and participated in it despite moral and religious scruples. Even antislavery religious groups like the Shakers of South Union in the Green River were shaped by their cultural environment and quietly tolerated the institution. Living in a slave society, the South Union Shakers faced situations that their doctrine had not prepared them to answer. For example, upon joining the church, members were required to give their wealth to the church community. But what if their wealth consisted of slaves? The leader of the Shakers, Elder John Rankin, wrote to northern Shaker communities asking for guidance in the matter. "Shall money which has been obtained

\footnotetext{
${ }^{36}$ Harold D. Tallant, Evil Necessity: Slavery and Political Culture in Antebellum Kentucky (Lexington: University Press of Kentucky, 2003), 1-3.

${ }^{37}$ Ibid., 63, 71, 77.
} 
by the sale of Negro slaves be refused or accepted by the Church of Christ?" he asked. And "if refused how far removed from the sweat and blood of the slave must money or property be to render such acceptable to the church? Our sugar and coffee come directly from the toiling slave thru his master and is acceptable."38

Even if the Shakers were reluctant to receive money gained from slavery, their market exchanges with slaveholding farmers and planters reinforced the institution. After purchasing the land that became South Union, the Shakers acquired a twelve thousand dollar debt with a local bank. To ensure that their community survived they were forced to do business with slaveholders. "As we cannot, in the present state of things, sell anything for money here, we must do something to get a little money, however venturesome the industry and undertaking may be." They established a textile factory where they received cloth from farmers and planters to "full, dye drab, shear once, and press." When the community did not produce enough to sustain themselves, they purchased crops produced from slave labor. "Paid Dr. Ray $\$ 25$ for one stack of hay," reads one entry. Another entry stands out. On July 24, 1843, Shakers "paid J. Proctor $\$ 10$ for the hire of Johnson," revealing that they hired slaves to perform work at South Union. $^{39}$

Shakers were not alone in opposing slavery for religious reasons. A small number of farmers also opposed the institution. The Reverend William Adams, a Methodist preacher, traveled around Warren County in the 1810s baptizing converts and spreading his antislavery views "with some degree of success." In 1817, he published an article

\footnotetext{
${ }^{38}$ John Rankin quoted in Marc A. Rhorer, "Believers In Dixie: A Cultural Geography of the Kentucky Shakers" (Ph.D. Diss., Florida Atlantic University, 2007), 182.

${ }^{39}$ Entries from Elder John Rankin account book, Sept. 1, 1814, July 24, 1843, South Union Shaker Collection, WKU.
} 
that condemned religious defenses of slavery and urged the church to take a stronger stance against the institution. "I am afraid that pitiful pamphlet," he worried, "will increase our divisions and disturb our peace." He found particularly troublesome local Baptists who took a strong proslavery stance. "I have no doubt that [a fellow minister's proslavery] statements with regard to the Baptists are correct. I find them applicable to the conduct in this region." But Reverend Adams's cause was also stymied by some within his church. Soon after his article appeared "contentious brethren" attacked him for his antislavery views. They "have the satisfaction," Adams noted, of "thinking they have beaten us and driven us out of such a field of controversy." "The spirits and practice of slavery," he lamented, "[are] prevailing., 40

Adams was right; slavery was prevailing in the Green River. The increase in the use of slave labor followed other important economic changes in the region. During the 1820 s improvements to the region's two largest rivers opened up new markets that impacted the local economy and eroded the barter system. Before 1820, most economic transactions in the Green River involved barter because cash was scarce. Some merchants even preferred payment in goods rather than money. William Reading in Russellville advertised that his merchandise would be sold at reduced prices to anyone willing to exchange "calves, cotton, whiskey, tallow, beeswax, and hogs lard.",41 Settlers could also purchase goods through barter. One speculator advertised that he had a "large quantity of military land warrants which he will dispose of upon reasonable terms for cash or likely horses as cash price." ${ }^{42}$ Individuals selling land knew cash was scarce on the frontier and allowed settlers to purchase land using other capital. John Felps

\footnotetext{
${ }^{40}$ Reverend William Adams letter to his church, Mar. 14, 1819, FHS.

${ }^{41}$ [Russellville] The Mirror, Nov. 1, 1806.

${ }^{42}$ [Lexington] Kentucky Gazette, Apr. 21, 1792.
} 
purchased "one hundred acres of land on the Green River" from Edward Bundy in 1807 for "fifteen pounds cash, a horse worth that, or good young cows or calves."43

By the mid 1820s, however, merchants were less willing to take goods in place of money because markets became more accessible through the region's waterways developed for commercial purposes. Moreover, the need for farmers to pay mortgages, taxes, and to purchase goods that could not be made at home encouraged them to participate in the market economy. The region transitioned from subsistence agriculture to market production. Farmers produced marketable crops and purchased a variety of goods, including coffee, pocket knives, kitchen utensils, and sugar from local merchants. ${ }^{44}$ Still, into the 1820 s and 1830 s two types of farmers lived in the Green River: subsistence farmers who produced only small amounts for market and those who produced primarily for sale. Small farmers grew limited quantities of cash crops such as hemp or tobacco though not on the scale of planters. But this became problematic for the sons of yeomen farmers who came of age in the 1820 s and 1830 s and lacked capital to purchase their own farms. As average-sized farms produced more, the value of land increased. Still, sons were expected to move out and start families when they reached adulthood or married. But few of them owned land. Young farmers starting out experienced longer periods of "dependence" before they could purchase their own farms. A strong correlation existed between youth and poverty, and age and wealth. In the census records, few farmers' sons between the ages of twenty and thirty owned their own property. More commonly, farmers became property holders in their mid-thirties to early

\footnotetext{
${ }^{43}$ Land Deed between Edmond Pundy and John Felps, June 10, 1807, Alexander Collection, WKU.

${ }^{44}$ Receipt from Sam P. Stiles to William Walker, Mar. 5, 10, 20, 1828; receipt from F. Cunningham, Aug. 31, 1833; receipt from J. Rankin, Sept. 1, 1836, William W. Walker Family Papers, FHS. See Elizabeth A. Perkins, "The Consumer Frontier: Household Consumption in Early Kentucky," Journal of American History 78 (Sept. 1991), 486-510.
} 
forties as they accumulated wealth. The "economic dependence and powerlessness of young adults," writes historian James Henretta, "was a fact of life.,45

If the desire to provide for their children drove yeomen farmers into the market, they decided how to exploit the market to maintain their independence. For most farmers investing in slave labor was the best option. Joseph Hornsby, a Shelby County farmer, kept a detailed journal of his slaves' activities between 1798 and 1804 that reveals how yeomen used slavery. One entry reads: "Saturday-clear, Davy plowing in the middle field, Diecy weeding corn there, Billy plowing in the apple orchard, John mowing." Yeomen farmers usually hired slaves for terms of one year, giving them access to slave labor through the entire season, from planting to harvesting. Farmers with slaves could clear more land, produce higher yields, and sell more goods at market. High yields correlated to the quality of the land, so farmers tried to protect their independence by settling on land near rivers and streams. Land deeds for most of the region's earliest settlers suggest they sought land on water. In 1796, William Frogett purchased two hundred acres of land on "duck spring run." ${ }^{.47}$ Andrew McFaddin patented one hundred acres of land in Barren County on the "Big Barren River."

Farmers with capital and those who could employ a slave throughout the year were more likely to own slaves. Larger farmers, lawyers, and doctors were the most frequent owners of several slaves. The latter used their professional income to support farming operations. Most yeomen could not hope to become professionals, but many

\footnotetext{
${ }^{45}$ McCurry, Masters of Small Worlds, 56; and James Oakes, The Ruling Race: A History of American Slaveholders (New York: W. W. Norton \& Company, 1998), 37-41. See also James A. Henretta, "Families and Farms: Mentalite in Pre-Industrial America," The William and Mary Quarterly, 3rd Series, 35 (Jan. 1978), 8 (quote). Like McCurry, Henretta argues that the road to independence for yeomanry almost always required becoming a laborer or tenant first.

${ }^{46}$ Joseph Hornsby Diary, entry for June 22, 1803, FHS.

${ }^{47}$ William Frogett Land Deed, July 20, 1796, WKU.

${ }^{48}$ Andrew McFaddin Land Deed, Dec. 21, 1798, WKU.
} 
middle class farmers apprenticed their young children to learn a trade or skill. Parents who could not give their children land apprenticed them in skilled trades to provide them with the tools they needed to succeed. Young Benjamin Burch of Warren County, for example, was apprenticed "with the consent of his mother to learn the art and trade of saddler crafting" for a term of three years. ${ }^{49}$ A skilled tradesman usually enjoyed increased income and could transition more easily into the slaveholding class. ${ }^{50}$

French émigré Nicholas Gautier quickly established himself as a successful farmer through investment in slave labor when he arrived in Logan County in the 1820s. Gautier lived on a four hundred acre farm with his wife and two children. "I live easy," he wrote to his brother in France, "my farm produces what supports my family." Gautier emphasized his own and his neighbors' self-sufficiency. "All citizens dress with great taste," he noted, "frequently in their own manufacturers as every farmer has spinners [and] weavers of his own." When financially able, Gautier purchased slaves to work on his farm and was quite pleased with his investment. "I have slaves to work for me," he wrote, "which affords me all the comforts of life and the luxuries to be had by every farmer." Not only did slave labor support Gautier and his family, but he clearly enjoyed the higher status and wealth slave ownership accorded him. "I have the pleasure to have it in my power to loan my neighbors a few hundred dollars when they want it."51

Yeomen at the other end of the socioeconomic spectrum were less fortunate. Some farmers never owned a slave and found renting a slave too costly. They relied solely on the labor of their dependents to harvest their crops. The trials of H. C. Powers, which he recalled in 1859 , reveals what many small farmers without slaves experienced.

${ }^{49}$ Benjamin Burch Contract, Jan. 6, 1827, WKU.

${ }^{50}$ See Oakes, The Ruling Race, 57-65.

${ }^{51}$ Nicholas Gautier to E. Gautier, Sept. 20, 1812, FHS. 
Powers's father died when he was a child, leaving the family struggling to support themselves. When he was a child, his mother worked the fields with the help of a neighboring ten year old boy because he and his brothers were too young to help. The following year he began to work in the fields. "Corn was to gather, tobacco was to strip and market and wood to get in for the winter," he recalled. His mother worked the hardest, having simultaneously to fulfill the role of her deceased husband and perform work inside the house. "My mother," he recalled, "work[ed] in the field all day and part of the night [and] sewing for her children." When the Powers family lost their land in a court battle, they were forced to become tenants. ${ }^{52}$

The percentage of slaveholders in the Green River was relatively low. The typical "slaveholder" in the Green River did not own any slaves at all. Rather these small farmers hired slaves depending on seasonal needs and economic opportunity and ability, moving intermittently in and out of the slaveholding class. What differentiated the Green River region from other parts of Kentucky was not the number of slaves but the percentage of whites who owned slaves. Smaller farmers did not require as much labor and owned fewer slaves. In roughly half of the Green River counties, 30 percent of the farmers owned at least one slave, but many more small farmers participated in the institution than the numbers suggest by renting slaves from their wealthier neighbors. ${ }^{53}$

When yeomen hired slaves from their planter neighbors contracts often stated specifically what labor the slave could perform. One contract stipulated that the slave was "to be treated humanely, not to be hired out of Henderson County, employed at any mill or coal bank, or hired out to anyone else." The hirer also promised to furnish the

\footnotetext{
52 "The H. C. Powers Story," 1859, Green River Research Collection, WKU.

${ }^{53}$ Aron, How the West Was Lost, 206.
} 
"negro with good summer and winter clothing, shoes, stocking, and blankets."

Sometimes slave hiring was seasonal. Yeomen often hired slaves during the busiest months of the harvest. Warren County mechanic and millwright John Rollins regularly hired slaves to help process his wool. "I understand you have a negro boy to hire," Hollins wrote slaveholder Dr. Sterman. "I feel very anxious to get one if I can [because] the time of steeling wool is at hand and I must [find] a boy to help me." Because steeling wool required some expertise, Rollins wanted to hire a slave for five years as "this thing of hiring one every year is very troublesome." "To learn him to card the first year will not pay," but "if he is a spritely boy," Rollins added, "I can make a good wool carder of him." Rollins articulated what many yeomen and planters knew. Slaves hired out to yeomen often learned additional skills which increased their value should they be hired out again. $^{55}$

Planter Peter McClanahan had regular interactions with yeomen farmers. McClanahan owned a moderate sized farm in Todd County where he grew tobacco for market. But he was also a doctor, and with the income from his profession he supported his farming and purchased several slaves. He also made some money on the side by renting small parcels of land to tenants. When he could not gainfully employ all his slaves he rented them out to his yeomen neighbors at a modest price. "Hired Moses from 1810 to 1814 at $\$ 37$ per year," Peter recorded in his logbook. McClanahan's rentals gave many small farmers the opportunity to benefit from slave labor, at least temporarily, without its risks and at a much lower cost needed to buy a slave outright. ${ }^{56}$

${ }^{54}$ Receipt from Francis E. Walker, Jan. 1, 1840, William A. Walker Family Papers, FHS.

${ }^{55}$ John W. Rollins to Dr. Sterman, May 6, 1824, WKU.

${ }^{56}$ Dr. Peter L. McClanahan Account books, entry for Jan. 1, 1822, WKU. 
Large planters also helped their smaller neighbors by offering a variety of services that they could afford because of their investment in slavery. When James Ashcroft needed the services of a blacksmith to fix his plow, he went to the local planter who did it for a small charge. Farmers too distant from town to market their crops could sell their surplus to the local planters who marketed it for them in exchange for a percentage or flat fee. Such arrangements saved small farmers the expense of transporting their goods to market. When Mary Powell needed to sell four hogsheads of tobacco she went to local planter J. Brandenburg, who purchased and marketed them for her. ${ }^{57}$

Commercial exchanges shaped social relationships in the Green River. When they turned to planters to hire slaves, market their crops, repair their equipment, and mill their grain yeomen did not become dependent "slaves" to the planters. Both parties engaged in a mutually beneficial commercial transaction. Though they did not posses equal social or economic power, they shared similar communal values. Both linked upward mobility to land and slave ownership. And when a planter displayed his wealth or offered his services to yeomen neighbors, he reinforced the link between wealth and slavery. ${ }^{58}$

Planters and small farmers were not the only inhabitants of the Green River to benefit from slave labor. The builders of the region's transportation infrastructure regularly employed slaves in the 1830 s and 1840 s. After F. Lucas agreed to build a road, he hired "four negro men" who worked for him "from this date [January $\left.2^{\text {nd }}\right]$ until the

\footnotetext{
${ }^{57}$ Receipt from J. W. McQuinn, Apr. 5, 1847, receipt from J. Brandenburg, May 30, 1843, both in Ashcroft Family Papers, WKU. See Eugene D. Genovese, "Yeomen Farmers in a Slaveholders' Democracy," Agricultural History 49 (Apr. 1975), 337-38.

${ }^{58}$ Oakes, The Ruling Race, 37-68. See also Jack Larkin, "The View from New England: Notes on Everyday Life in Rural America to 1850," American Quarterly 34 (Summer 1982) 244-61. Even though Larkin's account focuses on New England his ideas about social relationships built upon commerce describe the Green River in the early nineteenth century.
} 
$25^{\text {th }}$ of December for the sum of six hundred dollars." The "said negroes," the contract stated, "are to work on that part of the turnpike road leading from Bowling Green to Louisville between Barren River and the Dripping Spring." In addition to paying taxes on the slaves and furnishing their clothes, Lucas agreed to "take good care of them as if they were my own, and I am not to make them work when it is raining, or in extreme bad weather, and I am to allow those which have wives time every fourth Saturday to go and see them.. 59

Slave labor was extremely valuable and the loss of slaves could often lead to violence among whites. Stealing slaves from planters became a fairly common occurence. Thomas Middleton hired a few slaves to work his farm in 1830. The evidence is not clear, but a lawsuit erupted when the planter from whom Middleton hired the slaves sued the Thomas and his son John for alleged damages to his slave. When "the suit had gone against" Middleton and his son John, they "stopped the mail stage near Munfordsville and retained it at least one hour." Their intention was "not to rob the mail but to take from the men in the stage some negros that the party [in the stage] had stolen from him." The sheriff arrested the Middletons, small farmers who were "worth nothing," two hours later. ${ }^{60}$

To accomplish their long term goal of independence most small farmers became tenants until they could one day purchase their own land. Most were listed as "laborers" on census records, suggesting that they worked on their parents' farms until they could acquire enough wealth to purchase a farm of their own. Most did not become "independent" farmers until their early to mid-thirties. Rental agreements often

${ }^{59}$ J. F. Lucas Contract, Jan. 2, 1840, Hines Family Collection, WKU.

${ }^{60}$ W.W. Henry to J. Speed Smith, June 3, 1830, WKU. 
stipulated that a percentage of the renter's crops go to the land owner. Many contracts resembled the agreement between A. Windham and J. Townsend of Warren County. Townsend rented an unspecified amount of land from Windham to grow his crops. In return, he promised to give Windham "one third part of all the oats, one third part of the corn I can raise." If he grew any tobacco, he was "to pay him [Windham] what is wright [sic] per acre for the ground that I tend."

Though fathers worked hard to accumulate land and wealth to pass on to their children, it was often insufficient to secure their independence. The division of the estate between sons and daughters and the sale of a portion to satisfy creditors and pay for funeral expenses often left little for each descendant, certainly not enough to support a family. Samuel Davis willed "two-thirds of [the estate] divided among my children when they become of lawful age." ${ }^{.62}$ If the children had not reached adulthood when the father died the estate was to be left in the hands of the mother until the children matured. Such was the case when Mathis Henry of Warren County died in 1837. Having "implicit confidence in his wife's intentions to do right," he left her his estate "to dispose of as she may think most advisable for the benefit of our children." ${ }^{93}$

Wills could sometimes cause conflict, particularly when slaves were involved. Families with more children than slaves often fought over who would inherit the slaves. Susanna Coleman knew the potential for family conflict and hoped "a negro girl that father gave me and a valuable mare" would pass smoothly to her children. "I wish a division to take place in peace, harmony, and friendship throughout dealing justice to all

\footnotetext{
${ }^{61}$ Windham Letters, 1847, Ashcroft Family Papers, WKU. See also Paul W. Gates, "Tenants of the Log Cabin" Mississippi Valley Historical Review 49 (June 1962), 3-31

${ }^{62}$ Samuel Davis Will, undated, 1846, Warren County Wills, WKU.

${ }^{63}$ Mathis W. Henry Will, Dec. 1, 1837, Will Book N Warren County 1827-1862, entry 128, WKU.
} 
the heirs," she wrote to her brother. ${ }^{64}$ Unfortunately, conflict divided Catherine Stockton's Barren County family when she died in 1825 and left behind a young slave girl named Susanna. According to Stockton's will, her son James was to sell the slave and divide the money equally among her children and grandchildren. After three years, the slave remained "in the hands of James undisposed of." In response, James's brothers and sisters brought suit against him. The judge ruled in the family's favor and ordered that "the said negro girl be sold for money and the proceeds be divided according to the respective rights and interests. ${ }^{, 65}$ Most family members, when given the choice between inheriting a slave or cash from the estate, chose the slave as the wiser investment. "She wishes to send you the amount of her share," read one letter, "as she wants the negro boy." $" 66$

Rebecca Rowan's letters from the 1850s describe what faced many families who fell on hard times in the Green River region. They also reflect the changes that took place when the regional economy shifted from subsistence agriculture to market production. When her husband, a judge, died and left the family in debt, Rowan confronted many of the same problems as struggling yeomen families. She was forced to sell the family's livestock and slaves in an attempt to satisfy her creditors, but this left her without the ability to maintain the family's economic status. Deeply in debt, Rowan was unprepared to assume control of her husband's estate. She turned to an old family friend, Judge Caleb Logan, who offered advice and guidance about how to manage the farm. Rowan had to stave off creditors, provide for her four children, and attempt to make her

\footnotetext{
${ }^{64}$ Susanna Coleman to Collin M. Henry, Oct. 4, 1835, Coleman Family Papers, WKU.

${ }^{65}$ Catherine Garnett vs. Stockton, May 24, 1828, Barren County, Kentucky, Circuit Court, http://www.barrencoky.com/records/records.html.

${ }^{66}$ James Collin to Elizabeth McKinney, 1835, Coleman Family Papers, WKU.
} 
farm profitable again. Her letters express great anxiety as she was overcome by the burden suddenly placed on her. "It is a terrible feeling with the perfectly helpless family I have depending upon me alone to feel myself in utter darkness as to the state of my business," she wrote anxiously. "If I could get at a knowledge of my true condition I would then know how to act, for surely if I do not I see nothing but overwhelming debt and starvation. ${ }^{, 67}$

Judge Logan helped Rowan delay creditors to give her time to pay off the estate's debts. She believed that if "funds [could be] appropriated for the purchase of slaves" she could be "able to produce something from the farm wherewith to support my family and eventually liquidate all debts." If Judge Logan could not get her an extension to pay her debts she saw little hope for the future of her farm. "If the means are taken from me," she lamented, "my family will be impoverished or the farm will be a heavy burden instead of a source of revenue. $" 68$

Over time, Rowan fell deeper into debt. Lacking slaves or a horse she could not grow sufficient crops to raise money and satisfy creditors as well as produce food for her family. "I have no servant capable of work and am compelled to have my washing done in town at a cost of sixty dollars a year which is sufficient to pay the hire of a woman who could do all my work." She tried to find respectable occupations for her sons so "that they might clothe themselves, but in this miserable half dead place, there is nothing to bind them." With little income, Rowan found herself in the position of many small farmers and was forced sacrifice independence for income. She decided to take her children out of school, sending her two sons to "trade or hire them out as day laborers, a

${ }^{67}$ Rebecca Rowan to William Boone, Apr. 26, 1857, Rowan Family Papers, WKU.

${ }^{68}$ Rebecca Rowan to William Boone, Dec. 8, 1856, Rowan Family Papers, WKU. 
prospect at which my heart sickens, but this must be done or they must starve." Rowan devoted the family labor to growing subsistence crops, but could not grow enough food to feed the family. As a result, she purchased on credit, contracting an additional five hundred dollars debt. ${ }^{69}$

Owning more land than her two sons could work, Rowan decided to rent her surplus land to raise income. She soon received several offers, with prospective renters employing the land in different ways. A Mr. Speed "offers $\$ 225$ to take it by the year only and sub-rent to others as he has not force to work it all himself." A man named Connally, whom Rowan described as "poor but [with] good horses and wagons," seemed to promise Rowan the best use of her land. He "offers to build a log tenant house at [his] own expense and give two hundred dollars." He also promised to "put up a new fence and divide the land into fields to put one third in grass, one third in wheat, and the other third in corn and rotate the crops every year." In contrast, Felix G. Murphy, a well known planter in the region, proposed an eight-year lease. "He proposes to put one fourth of the land in wheat, one in grass, one in corn, and one in oats, rye, etc. and rotate the crops," Rowan wrote. Murphy "offers to rent in this way, or, I should say, pay the rent in this way." "By this management," she concluded, "he says he would improve the farm and make it more valuable than it ever was." ${ }^{\prime 70}$

Yeomen farmers moved to the region in the 1790 s and early 1800 s seeking independence and land to support their families. In the early years of the Green River's history this was relatively easy because of equitable land distribution from Virginia military land claims and the 1795 state law that enabled squatters to purchase land. The

${ }^{69}$ Rebecca Rowan to William Boone, Aug. 31, 1856, Apr. 26, 1857, Rowan Family Papers, WKU.

${ }^{70}$ Rebecca Rowan to William Boone, Apr. 26, 1857, Rowan Family Papers, WKU. 
earliest white settlers brought slaves with them, and the institution shaped and influenced the society and economy of the Green River. Though few small farmers owned slaves, slave renting was common among them and they benefitted from the institution. Slavery became even more engrained as the region moved from subsistence to market-oriented production. By the 1820 s and 1830 s, the sons of yeomen farmers who first settled the Green River found economic conditions more difficult. The price of land increased often putting independence beyond the reach of young farmers starting families. Many were forced to rent land until they could save enough money to purchase their own farms.

The unique settlement of the Green River created one of the most "Democratic" regions in Kentucky. Virginia's system of land claims for service during the Revolutionary War, although a failure in some ways, laid the foundation for the preponderance of small farmers who populated the region. Squatters seeking a piece of land big enough to support their families preceded veterans, but their precarious claims and "homestead ethic" carried little weight beyond the frontier and conflict arose between squatters and speculators. The Kentucky legislature sided with the squatters and allowed them to purchase the land on generous terms. Once settled, farmers cleared land and began to farm. Slave labor was crucial for this work and most farmers benefitted from the institution by owning slaves or renting them from a neighbor. Maintaining their "competency" from "slave like" dependence was one of the yeomen's greatest concerns. Their investment in slave labor to harvest more crops was designed to protect their independence.

Slavery became deeply engrained in Green River society after the 1820 s. But the growth of slavery was only one effect of larger economic changes that took root early in 
the Green River's history and influenced the region socially and politically. After 1805, a powerful push for internal improvements in the region expanded farmers' market connections and sparked a transition from subsistence agriculture to market production. 


\section{CHAPTER TWO}

\section{POLITICS AND THE RISE OF GREEN RIVER'S MARKET ECONOMY}

1800-1820

The political history of the Green River reflected the social and economic changes in the region. Early Green River politicians fought for the rights of small farmers and squatters, who first settled the region. They won important victories in the form of debt relief and land grants. The Green River Band, a group of politicians led by Felix Grundy, spearheaded these political efforts. Grundy and his allies successfully challenged the political dominance of Bluegrass aristocrats associated with Henry Clay until the middle of the first decade of the 1800s. The Grundy faction supported legislation that enabled small farmers to purchase land from the state and settle in the Green River, but it increased the state debt when small farmers defaulted on their payments. The state's growing debt eventually undermined the Green River Band's political clout. Politically hampered, Green River politicians abandoned the interests of small farmers and supported legislation they had once fought to prevent.

The introduction and expansion of banking in the state after 1805 was an outgrowth of this political reversal. In 1807, the Green River received its first bank, a branch of the Bank of Kentucky. Soon after, Green River merchants petitioned their local governments for increased internal improvements, including clearing the Green and Barren Rivers. These economic changes profoundly affected politics. By the 1820 s, land 
ownership was no longer synonymous with economic independence as it once had been. Instead, Green River politicians preached the virtues of commerce as markets became more accessible through internal improvements. These changes transformed the world of small farmers and opened new markets they quickly embraced.

From early settlement, the Green River embodied Thomas Jefferson's republican principles. Jefferson believed that the stability of republican government depended upon the availability of western land where small farmers could settle their families and earn a living. In his Notes on the State of Virginia, Jefferson argued that yeomen farmers embodied a virtuous citizenry because they were "self-sufficient." "Those who labor in the earth are the chosen people of God," he wrote, "whose breasts he has made his peculiar deposit for substantial and genuine wisdom." Jefferson was wary of anything that threatened to undermine the economic security and independence of small farmers, including banks which he believed entrapped them in debt. Indebted farmers, he argued, could not rely on their own and their families' labor to sustain them. Dependent farmers, Jefferson believed, signaled the breakdown of republican virtue. ${ }^{1}$

Federalist Bluegrass politician like John Breckinridge opposed Jefferson's agrarian-based republicanism. The Federalist Party grew from the political and economic theories of Alexander Hamilton. Federalists called for a strong central government that encouraged and protected home industries through banking and protective tariffs. These ideas resonated with merchants, manufacturers, and the Bluegrass elite, most of whom were large slaveholders who produced for market. ${ }^{2}$

\footnotetext{
'Thomas Jefferson, Notes on the State of Virginia (Richmond: J. W. Randolph, 1853), 176.

${ }^{2}$ See Lowell H. Harrison and James C. Klotter, A New History of Kentucky (Lexington: University Press of Kentucky, 1997), 72-79; and Stephen Aron, How the West Was Lost: The Transformation of Kentucky from Daniel Boone to Henry Clay (Baltimore: The Johns Hopkins University Press, 1996), 95-101.
} 
The political contest between Federalists and Democrats began when the Kentucky legislature debated how to dispose of unclaimed military land warrants from the Green River. John Breckinridge and his fellow Bluegrass politicians wanted to sell unclaimed land to the highest bidder to raise revenue for the state. But Breckinridge and his allies could not ignore the pleas of Green River politicians who urged the assembly to sell the land to small farmers at low prices and long credit. Throughout the $1790 \mathrm{~s}$, Green River squatters lobbied the state for pre-emption laws that would allow them to purchase the land on which they settled. In 1793, squatters pleaded that the legislature let them buy the "vacant land" they had "at great risk, trouble, and expense, settled."

Squatters had reason to fear speculators' interest in the region. Many speculators vied for control of Green River lands, but in 1795 the Kentucky legislature sided with the region's small farmers. They passed a law that allowed all squatters currently residing on land a chance to purchase it. The legislation stated: "Whereas a number of people have settled themselves on the vacant land South of the Green River, under a belief that they were no longer liable to be taken by military warrants, and that the legislature would grant them settlements therefore, on paying a moderate price for same and it is therefore thought proper to pass an act for that purpose." After two years, squatters who improved their land—building a cabin and raising crops — had the land deeded to them. The legislature's decision to sell unclaimed land to small farmers rather than speculators had less to do with their belief in Jeffersonian principles and more with politicians' recognition of the steadily growing political clout of the Green River. Counties formed quickly as settlers poured into the Green River. Six counties were created between 1793

\footnotetext{
${ }^{3}$ James A. Ramage, "The Green River Pioneers: Squatters, Soldiers, and Speculators," Register of the Kentucky Historical Society 75 (July 1977), 181.

${ }^{4}$ Ibid.
} 
and 1799 , another three in the first decade of the new century, and six more between 1811 and 1826.

The assembly's decision to favor squatters over speculators reflected an attempt to win over the region politically. Political moderates became the deciding factor when they threw their support behind the Green River squatters. Recognizing the rapid growth of the region, they worried about the possibility of future political conflict and violence if small farmers were denied land. In contrast, enabling settlers to purchase their land tied them to the state government and prevented a possible rebellion similar to the Regulator movement in North Carolina twenty years earlier. As historian Fredrika Teute points out, Kentucky's willingness to incorporate "the un-propertied into the body politic, divert[ed] attention away from radical action over economic qualities [related to unequal land distribution].

Largely freed from speculators and given generous homesteading terms, settlers poured into the Green River in the late 1790s. Bluegrass politicians watched with contempt. John Breckinridge expressed typical Bluegrass scorn for the Green River after learning a friend planned to move there: "And what are you about to exchange all of this for? A country you have never seen; a country when you do see, you will see filled with nothing but hunters, horse thieves, and savages. And a country where wretchedness, poverty and sickness will always remain."6

Small farmers elected politicians who reflected their small farmer values, or at least professed to do so. Electioneering took place at the local level. Political aspirants

\footnotetext{
${ }^{5}$ Fredrika Johanna Teute, "Land, Liberty, and Labor in the Post-Revolutionary Era: Kentucky as the Promised Land" (Ph.D diss., The John Hopkins University, 1988), 4-5.

${ }^{6}$ John Breckinridge, quoted in, Joseph Howard Parks, Felix Grundy, Champion of Democracy (Baton Rouge: Louisiana State University, 1940), 7.
} 
toured the countryside claiming to be "friends of the people." But politicians also had to demonstrate their support for farmers. One voter described Democratic candidate Matthew Lyon as a "good electioneer" because he could "drink grog all the day long without getting drunk" and "tell pretty good rough anecdotes." Indeed, any candidate who refused to share drinks with his constituents was unsuccessful. "It would have been an insuperable objection to a candidate for office," wrote one voter, "if he did not drink."”

Felix Grundy did not seem the right candidate to defend small farmers' interests when he arrived in the Green River. Born to a wealthy family in Berkeley County, Virginia, in 1777 , he moved to Kentucky in 1780 . His parents hired private tutors to educate him. He became interested in the law and worked as an assistant in the prestigious Lexington law office of George Nicholas, who played an important role in writing Kentucky's first constitution. In 1797, he opened up his own law firm in Bardstown, but soon moved to the Green River where the demand for lawyers was growing because of conflicting land claims. In this litigious environment, he established a successful practice and invested in land and slaves. ${ }^{8}$

Though Grundy came from a privileged background, he believed in Jeffersonian principles. Grundy argued that government must make land available to settlers. Like Jefferson, Grundy distrusted banks and their power to jeopardize the independence of small farmers. In 1792 , he proved his loyalty to his small farmer constituents and made his mark on Kentucky politics when he attempted to decentralize the state's legal system by calling for the creation of circuit courts. The current court system, he argued, afforded "ease and convenience" to only some of Kentucky's population. According to

\footnotetext{
${ }^{7}$ Aron, How the West Was Lost, 162.

${ }^{8}$ Ibid., 161.
} 
Kentucky's 1792 constitution, one court handled all grievances for several counties and sheriffs rarely tried court cases in the same county where the problem occurred. This created a problem for small Green River farmers who faced legal problems. Small farmers did not have the time or the money to travel great distances to defend themselves in court. Breckinridge blocked Grundy’s 1792 proposal. $^{9}$

By logrolling and voting together, the small Green River group successfully challenged Bluegrass dominance of the Kentucky House. This strategy made them politically "formidable." "Its votes were for barter and exchange," one politician wrote of the Green River Band, "you vote for my law; we want indulgence, we want something done for Green river and we will vote for yours." 10

As a politician, Grundy realized that he needed the support of wealthy Green River residents. On occasion, he defended speculator interests as well as those of small farmers. In 1801, surveyor Samuel Pottenger agreed to locate twelve thousand acres of "good tillable land" in the Green River for speculator Andrew Beall. In return, Beall promised to pay Pottenger 3,800 acres of land upon completing the survey. But Beall sold the land he had promised to Pottenger and offered him instead land of "inferior quality." When Pottenger learned of Beall's transaction, he sued him. In court, Grundy defended Beall's actions claiming that the land he offered Pottenger was "of superior quality" and had "superior local qualities" because it was "contiguous to the Green River." "11

\footnotetext{
${ }^{9}$ Parks, Felix Grundy, 15.

${ }^{10}$ Parks, Felix Grundy, 17.

"Felix Grundy Deposition, Apr. 3, 1801, Buell-Pottenger Letters, Filson Historical Society, Louisville, Kentucky (hereafter FHS).
} 
Breckinridge and Nicholas feared the political power of the Green River during the rewriting of the state's second constitution in 1799 , which reopened the debate over slavery. Bluegrass politicians knew that the region was largely composed of small farmers who did not produce for market and assumed they opposed the institution. The Green River had not posed a problem during Kentucky's first constitutional debate in 1792 because of its small population. Over the next seven years, however, the population grew rapidly and new counties formed quickly. Breckinridge and Bluegrass planters who depended on slave labor feared the political and economic repercussions of Green River interference in the constitutional debate. Erroneously, they believed Green River farmers opposed slavery because their small, subsistence farms did not depend upon slave labor. Nevertheless, Breckinridge wasted little time and worked to prevent the possibility of Green River obstruction. He attempted to oust Grundy's constituents by establishing a property qualification for voting, limiting male suffrage to those who paid an "annual tax equal to the tax on 500 acres of first rate land." Few Green River yeomen farmers owned more than three hundred acres of land, and even those who did own five hundred acres or more remained ineligible to vote because all land in the Green River was qualified as second-rate. $^{12}$ The measure was shot down by a vote of forty-one to eleven. Breckinridge next urged that state representation be based on each county's population. He and Nicholas passed this resolve in the legislature, temporarily nullifying Green River dissent that might pose a threat to slaveholders. ${ }^{13}$

Breckinridge learned he had other reasons to fear Grundy and his allies. Green River politicians sought to democratize the Kentucky legislature and produced legislation

\footnotetext{
${ }^{12}$ William E. Connelley and E. Merton Coulter, History of Kentucky, 2 vols. (New York: American Historical Society, 1922), 1:401.

${ }^{13}$ Parks, Felix Grundy, 25;.Harrison and Klotter, A New History of Kentucky, 78.
} 
that helped small farmers become landowners. In 1798, Grundy introduced a bill that enabled small farmers to pay off land they purchased from the state government in four equal payments over two years. A few months later, Grundy's allies reintroduced and changed the bill so that yeomen had twelve years to pay off their mortgages.

Breckinridge and the Bluegrass politicians attempted to set deadlines for the payment of Green River land debts, but could not overcome the efforts of the Green River Band. Small farmers' debts remained a persistent thorn in the side of Bluegrass politicians. Because of the Green River Band's success in getting extensions, the debt, originally due in full by 1799 , dragged out until 1823 . By then, it amounted to over thirty-three thousand dollars. ${ }^{14}$

In 1802, Grundy and his allies resumed their attack on Kentucky's court system. When conservatives attempted to block all debate on the issue, the "cunning and intriguing" Grundy sparked a debate that went on for four days in "great heat, animosity, and party spirit."15 Members who wanted to extend the existing court system but did not necessarily support Grundy saw this as an opportunity and threw their aid behind Grundy to pass the bill. Bluegrass conservatives were furious. "Grundy and his coadjutors will have much to answer for," complained Henry Innes. "Ten years has been almost lost to litigants by the improper interference of our General Assembly."16

Grundy and Clay clashed again in 1802 over the charter of the Kentucky Insurance Company. With Grundy distracted by the circuit court bill, a group of Lexington merchants successfully petitioned for a corporate charter for an insurance company. Ostensibly designed to insure boats and their cargo on the Mississippi and

\footnotetext{
${ }^{14}$ Aron, How the West Was Lost, 158.

${ }^{15}$ Parks, Felix Grundy, 13.

${ }^{16}$ Henry Innes, quoted in, Parks, Felix Grundy, 18.
} 
Ohio Rivers, the Kentucky Insurance Company was in reality a bank with the power to issue paper money. No restrictions existed in the company charter to limit the number of notes the bank could print and the company did not guarantee the value of its notes. The company's charter was granted until 1818 and forbid the Kentucky legislature from chartering any other insurance companies during its lifetime. ${ }^{17}$

The legislation gave the corporation power to lend money and charge interest on its loans. Grundy was furious and he made repeal of the bank the focus of his 1803 reelection campaign. He toured the Green River region denouncing a corporate charter that, he claimed, would shift power to the Bluegrass "nobility." Grundy attacked the bank's ninety-day loan policy, which he argued did not give small farmers enough time to pay their loans. If the charter was allowed to stand, he declared, it would "create a distinction among our citizens and promote the spirit of aristocracy, which is already too prevalent." ${ }^{18}$ Grundy demanded that the charter for the Kentucky Insurance Company be revoked as it was obtained through fraud and deception.

Grundy and his allies' attacks on the Kentucky Insurance Company made him many enemies in the Kentucky legislature. One supporter of the bank wrote to a Lexington newspaper under the name of "A Poor Farmer." In his view, Grundy's supporters were sheep who blindly followed their leader. They sat beside Grundy "like staring statues, too ignorant to comprehend one word that fell from their leader, and too wise to utter a single sentence themselves." Leading the attacks on the banks was Grundy, "profoundly skilled in the art of intrigue."19

${ }^{17}$ Connelly and Coulter, History of Kentucky, 1:512.

${ }^{18}$ Aron, How the West Was Lost, 159.

19 "A Poor Farmer," in Lexington Kentucky Gazette, Jan. 29, 1805. 
Supporters of the Kentucky Insurance company knew they needed to undercut Grundy's opposition. They turned to Henry Clay. As a stockholder in the company, Clay had personal reasons for protecting the bank and he seemed the perfect candidate to defend it. By 1803, Clay had developed a reputation as a defender of corporate charters and other members appreciated his "spirit of direction and eloquence."20 Revoking a charter that had been legally granted to a company, Clay believed, would make Kentucky "a reproach among all nations of the earth." Clay also cited the economic benefits the bank would bring to Kentucky, arguing that banks encouraged increased commerce and promoted internal development. Behind the scenes, Clay persuaded many who opposed the bank to switch their votes. The turning point came when Clay convinced the representatives from two Green River counties, Henderson and Muhlenberg, to support the bank. With their votes, the bank was saved by a narrow margin of one vote. ${ }^{22}$ Happy Bluegrass politicians credited Clay for the victory over Grundy. "I am happy," one politician wrote, that "the Bank has had means of resisting the attacks of that unprincipled demagogue Grundy.",23 Another Bluegrass politician advised Grundy to "go home to your pillow" and "learn how to be animated with the honorable desire of purchasing a just renown, by promoting public happiness." 24

Grundy did not give up and his growing influence became apparent in the 1804 election for the U.S. Senate. Kentucky senator John Brown ran for reelection, opposed by Judge Buckner Thurston and John Adair. Adair claimed to represent the Green River but lived on a large plantation which produced "annually thirty or forty hundred weight

\footnotetext{
${ }^{20}$ Lexington Kentucky Gazette, Jan. 23, 30, 1806.

${ }^{21}$ Parks, Felix Grundy, 24.

${ }^{22}$ Aron, How the West Was Lost, 159.

${ }^{23}$ Parks, Felix Grundy, 25.

24 "A Poor Farmer," in Lexington Kentucky Gazette, Jan. 29, 1805.
} 
of corn per acre." Nevertheless, he had a good reputation among Green River homesteaders and Grundy used his resources to support Adair's election. Grundy began by circulating stories of Brown's alleged involvement in negotiations with Spain, a secret deal between James Wilkinson and Estéban Rodriguez Miro to make Kentucky a Spanish colony in return for trading rights on the Mississippi River. Grundy's influence worked, particularly among Green River representatives who gave Adair twenty-two of his thirty votes. Bluegrass politicians Thurston and Brown trailed Adair with eighteen and fourteen votes respectively. ${ }^{25}$ When Adair's victory seemed assured, Henry Clay entered the political contest. Unable to distance Brown from the Spanish conspiracy, Clay rallied support for Thurston, and the House vote tied at thirty. But with the Senate slightly more in favor of Thurston he won the election. Bluegrass conservatives credited their narrow victory to the "artful management of Henry Clay" who "worked [Adair] out of the election." For now, Clay had "proved entirely too hard for Grundy in all the pinches."26 The same year, opponents succeeded in revoking some of the powers granted to the Kentucky Insurance Company by its original charter. They repealed the provision that prohibited the legislature from chartering another insurance company, and passed a measure that limited the number of notes it could print. The law stated that "the notes" that the Kentucky Insurance Company "shall at any time issue, shall not exceed the debts due to them, the money in their vaults, the property, real, personal or mixt." To enforce its provisions, the act made the "said president and directors . . liable . . . out of their

${ }_{25}^{25}$ Parks, Felix Grundy, 21.

${ }^{26}$ Ibid. 
private individual fortunes" for any notes the bank printed in excess of what the law allowed but failed to redeem. ${ }^{27}$

Grundy, however, sought more. In 1805, he again demanded the revocation of the insurance company's charter. Both Grundy and Clay took to the floor to debate the issue. Banks were "inimical to a free Government," Grundy proclaimed, because they divorced profit from the laboring hands who produced it. Clay maintained that to revoke a company charter granted by Kentucky's legislature was unconstitutional. This time, Clay was unable to mobilize enough supporters. The election of 1805 swept many antibank men into the House and had political aftershocks in the Senate. At the time senators were not directly elected by the people but by members of the House. The fourteen additional votes in the House gave the Green River party enough support to elect John Adair, a representative from the Green River. The additional votes also allowed the House to revoke the bank's charter by a vote of thirty-seven to nineteen; a majority in the Senate concurred. ${ }^{28}$ Governor Christopher Greenup, a Clay supporter, vetoed Grundy's bill. He argued that dismantling the bank would ruin investors financially and reduce agricultural production throughout the state. The Grundy-led assembly overturned the veto. Grundy, it appeared, had finally won and friends of the bank became "sorely troubled and their countenances fell." 29 Fearful of Grundy's rising political power, Breckinridge again tried to oust Grundy from office to protect Clay's banking reforms and avoid running against the "indefatigable Felix" in the next Senate election. Breckinridge offered Grundy an appointment as commissioner in Louisiana, but Grundy

\footnotetext{
${ }^{27}$ Connelly and Coulter, History of Kentucky, 1:512-13.

${ }^{28}$ Parks, Felix Grundy, 27.

${ }^{29}$ Ibid.
} 
realized that Breckinridge was trying to get him out of the state and declined the position. $^{30}$

Just when the defeat of the Kentucky bank seemed assured, Clay proposed a bill that saved the institution. Clay's bill called for the immediate payment of the Green River's outstanding land debt. The bill split Grundy's Green River Band by forcing them to choose between destroying the bank or abandoning their constituents. They chose to protect farmers' claims. Anti-bank men who had voted for Grundy's bill to repeal the charter of the bank now voted to defend the bank. Once again, Clay's political management saved the Kentucky Insurance Company. ${ }^{31}$ The company weathered harsh opposition from its critics during its first few months in operation. Rumors circulated that the bank was guilty of favoritism in providing credit, was secretly owned by English capitalists, and was responsible for the increase in insurance rates. Despite the negative attention, the bank succeeded. The company's notes circulated in Kentucky and out of state above par at 102 percent. In 1818 , the legislature was so pleased with the operation of the company that it extended the charter another ten years. ${ }^{32}$

The company had little financial impact in the Green River because it extended its capital mostly in the Bluegrass. But its success whetted the appetite of Green River politicians and merchants to bring banking to their own region. They witnessed how the company encouraged manufacturing in the Bluegrass. As a result, Green River politicians supported the charter of the Bank of Kentucky during the 1806 legislative session. The charter organized the bank with a capital of one million dollars consisting of ten thousand shares worth one hundred dollars each and available at all branches. The

\footnotetext{
${ }^{30}$ Parks, Felix Grundy, 25; Harrison and Klotter, A New History of Kentucky, 78.

${ }^{31}$ Aron, How the West Was Lost, 160.

${ }^{32}$ Connelly and Coulter, History of Kentucky, 1:513.
} 
bank's mission statement stated, "The corporation shall not directly or indirectly deal or trade in anything except discount bills of exchange, current money, or in the sale of goods and produce really and truly pledged for money lent and not redeemed in time." The state and bank directors shared control of the bank with the state, having the power to appoint six of the twelve directors. ${ }^{33}$

The year after the Bank of Kentucky's charter, the Green River received a branch in Russellville. Despite the support it won in the legislature from Green River politicians, the Democratic attitude toward banking prevailed among farmers who viewed it as a threat to their independence. In its first few years of operation, the bank received little business other than a small number of loans for land debt. The lull in business was due in part to unfortunate timing. In 1807, Thomas Jefferson's embargo closed the port of New Orleans, the principle market for Green River farmers. Jefferson wanted to maintain U.S. neutrality while the Napoleonic Wars raged in Europe. His embargo restricted trade between the U.S. and the war's two major combatants, Britain and France, and caused New Orleans's exports to decline by almost 90 percent between 1807 and 1809 . The closing of New Orleans cut off Kentucky farmers from the global market. Money became scarce and the purchasing power of the region's farmers and merchants declined sharply. ${ }^{34}$

To boost business, the bank appealed to its predominately agricultural base and offered loans to pay off land debts. The bank advertised a "preference in discounts" to any farmer taking out a loan to pay for their land. The tactic was unsuccessful. One bank

${ }^{33}$ Ibid., 1:513-14.

${ }^{34}$ Dale Maurice Royalty, "Banking, Politics, and the Commonwealth, Kentucky, 1800-1825" (Ph.D. diss., University of Kentucky, 1972), 67-69. 
officer lamented that appeals to farmers had "little effect on my fellow citizens." 35 The bank began to fail when notes of the Russellville branch lost value. Branches in Frankfort and Lexington refused to take Russellville's notes, worried about their own supplies of specie. In 1809 , the problem grew worse. The value of the Russellville branch's notes in circulation dropped 54 percent and its specie supply fell 55 percent from January to August. ${ }^{36}$ In 1810 , negotiations between the Russellville branch and Frankfort branches produced an agreement to save the Green River bank. The Frankfort branch agreed to accept Russellville notes after the Green River branch deposited specie and funds from banks in eastern states in Frankfort. The Russellville bank amassed the funds by purchasing ten thousand dollars of stock from the Bank of Pennsylvania. These changes stabilized the Russellville branch, increasing its specie reserves and its notes in circulation. $^{37}$

Geography also limited the impact of the bank on the region's early economic development. The bank's potential to expand commerce in the Green River was undermined by distant markets and unreliable transportation. With limited access to markets, expanded bank capital promised few benefits for Green River residents. The solution, many argued, was developing internal improvements to facilitate access to market. $^{38}$

Merchants who supported internal improvements often faced criticism from farmers. Many farmers distrusted merchants because it appeared they manipulated the market for their own gain. In 1794, a "Farmer," writing in the Kentucky Gazette labeled

\footnotetext{
${ }^{35}$ Aron, How the West Was Lost, 163.

${ }^{36}$ Royalty, "Banking, Politics, and the Commonwealth," 71, 77.

${ }^{37}$ Ibid., 80.

${ }^{38}$ Helen Bartter Crocker, "Steamboats for Bowling Green," The Filson Club History Quarterly 46 (Jan. 1972), 11.
} 
merchants "void of humanity." He claimed that they undermined the community by causing "the distress of those on whom we depend for subsistence." Traveler François Michaux also noted the "dangers" of merchants. "[Local merchants] are always able to fix in their favor," he wrote, "the course of colonial produce which they take in exchange for their goods." Green River merchants who tried to expand their business faced the danger of eroding local support. ${ }^{39}$

It took a great deal of time for goods to reach the Green River. Merchants and professionals often purchased goods from Pennsylvania. Flatboats carried goods down the Ohio River to Louisville where they were unloaded. The only way to transport goods into the Green River was by wagon pulled by horses or mules. The region's roads were crude and often impassable in bad weather. Several waterways ran through the Green River, but these were largely unusable. Many rivers were too shallow for boats loaded with a significant amount of goods and many of those deep enough to navigate were blocked by debris. ${ }^{40}$

\footnotetext{
39 "Farmer," quoted in, Craig T. Friend, "Merchants and Markethouses: Reflections on Moral Economy in Early Kentucky," Journal of the Early Republic 17 (Winter 1997), 559.

${ }^{40}$ Crocker, "Steamboats for Bowling Green," 11.
} 
Figure 2: $\quad$ Sketch of a Flatboat

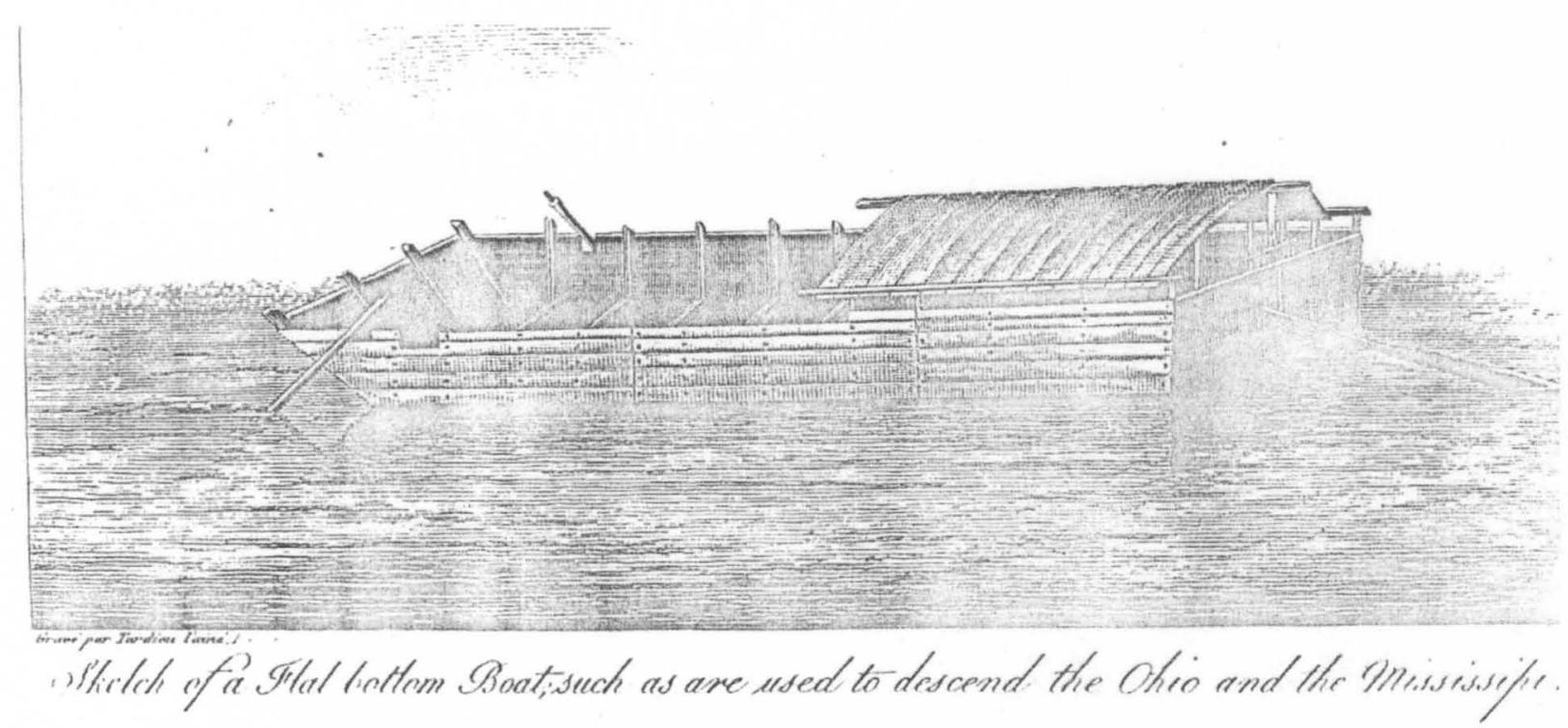

Source: Green River Research Collection, WKU.

Green River politicians and merchants believed the city of Bowling Green, located roughly thirty miles from the Barren River in Warren County, would benefit from river trade. The city's frustrated merchants experienced delays in shipments of goods and had difficulty expanding their businesses. Between 1800 and 1810, business owners in the town successfully petitioned Warren County leaders to clear rocks, fallen trees or "snags," and sand bars from the river so boats could come further inland. "To bring up a steamboat in the condition of the Barren River," complained local merchant Jacob Skiles, "was absolutely impossible. The short bends, over hanging timber and the fixed snags made the thing impracticable." Bowling Green leaders called on volunteers to clear the river. Young men from the countryside answered. "After working sixty days, often up to their necks in water, [the] Barren River was cleared to a sufficient extent to admit the passage of a small boat. ${ }^{.41}$

\footnotetext{
${ }^{41}$ Ibid., 12.
} 
Crude as this improvement was, it had a significant impact on the region's economic development and residents realized the benefits of clearing the Green River. Removing snags enabled boats to travel up and down the Barren and Green Rivers. Settlers commonly used flatboats to transport goods to New Orleans. Green River farmers adopted flatboats for commerce because they were relatively easy to construct and low drafts allowed them to travel in shallow rivers. The boats were rectangular and often had a small cabin for passengers. They carried a surprising amount of goods, anywhere between ten to seventy tons depending on their size. However, the boats were difficult to maneuver. Flatboats were steered by the use of oars, making it hard to avoid obstacles in the river. The boats often hit sandbars and got stuck or hit snags and took on water. ${ }^{42}$ After the rivers were cleared of debris, citizens petitioned their local governments for the right to harness the power of local waterways. In 1806, Green County resident Thomas Trew received permission to construct a mill on the Green River after the county government determined it would bring "great advantages to the community at large. ${ }^{\$ 3}$

Civic leaders constructed an extensive network of locks and dams that connected Bowling Green to the Barren River and allowed boats to reach the city. By 1830 , Bowling Green was no longer isolated. Manufacturing grew rapidly in the city and small farmers who lived nearby were encouraged to participate in the market economy. Enterprising farmers like Henry Fox of Bowling Green took advantage of these improvements. Fox grew up on the river and as a boy helped his father and neighbors

\footnotetext{
${ }^{42}$ Harrison and Klotter, A New History of Kentucky, 51-52.

43 "An Act Authorizing Thomas Trew to build a mill on Green River," Dec. 21, 1806, Green River Research Collection, Kentucky Library, Western Kentucky University, Bowling Green, Kentucky (hereafter WKU).
} 
build flatboats to carry their goods to New Orleans. As an adult, Fox became a carpenter and a farmer. He continued building flatboats and when he had surplus crops or livestock to sell he shipped them himself to New Orleans. "I used to flatboat it down to New Orleans," he recalled in his later days, and "took tobacco down. Sometimes I took beef cattle down, [other times] hogs, corn, and everything else that was made in this country." In New Orleans, farmers sold their goods and flatboat, and walked home, known as "wooding it." "I always came back by steamboat," recalled Fox, "and always paid an extra dollar to keep from wooding." After several years, he decided to become a full time steamboat driver. ${ }^{44}$

Small farmers often sold livestock such as pigs and cows in New Orleans markets. When he moved to Barren County in 1812 , Jonathan Loving was amazed at the fertility of the soil and the potential for raising livestock. This "flower of the western country," he wrote to his brother, produces crops that "far exceed anything you have ever seen." He also realized that many of his neighbors profited from raising livestock. "Some of my acquantices [sic]," he wrote, "have turned their attention [to cattle and] have sold to the amount of 50 steers at $\$ 12$ to $\$ 15$." "There have been more than 2,000 steers collected south of the Green River this summer all to be driven north," he wrote. Through cattle "people here are marching in the road to wealth quicker ... than in Virginia and that wealth is acquired with more ease." Loving encouraged his brother to move to the Green River to give his children "something to start them in the world." the most profitable trade for yeomen farmers. After the Napoleonic Wars, the West Indies and several countries in Europe began to produce tobacco in great quantities,

44 "Recollections of Henry Fox," 1812, Green River Research Collection, WKU.

${ }^{45} \mathrm{~J}$. Loving to S. Loving, Aug. 19, 1812, WKU. 
driving prices down. In response, many southern farmers switched to livestock, which they transported on the hoof to northern and southern markets. Kentuckians raised livestock bound for Baltimore, Philadelphia, Richmond, and Knoxville. By the 1820s, Kentucky drovers led thousands of livestock to market along the Wilderness Road. ${ }^{46}$ During the 1810s, manufacturing also became an important part of Kentucky's economy. More industrial corporations were chartered, many with capital from the Bank of Kentucky. Many elites and political leaders understood the role corporations played in Kentucky's economic growth. Southern corporations were as economically successful as their northern counterparts. As historian Robert E. Wright notes, by 1830 the Ohio Valley slave states-Virginia and Kentucky — enjoyed a greater per capita income than the free states of Pennsylvania and Ohio. Agriculture fueled economic growth in the Ohio Valley, but Kentucky's economy became increasingly diversified as insurance, banking, transportation, and manufacturing corporations appeared. ${ }^{47}$

But in the Green River, banks did little to spur economic development. No evidence exists that the Russellville branch invested in internal improvements. It had few demands for manufacturing loans and bank officers considered investments in manufacturing too risky. ${ }^{48}$ Instead, most manufacturing took place within the household using family labor. In 1812, Barren County had 747 looms that produced over 128,000 yards of cloth. The same year, Logan County's 595 looms produced an impressive

\footnotetext{
${ }^{46}$ Elizabeth Parr, "Kentucky's Overland Trade with the Antebellum South," Filson Club Historical Quarterly 2 (Jan. 1928), 73; also see Frank L. Owsley, Plain Folk of the Old South (1949; Baton Rouge: Louisiana State University Press, 2008); and Robert Mitchell, Commercialism and Frontier: Perspectives on the Early Shenandoah Valley (Charlottesville: University Press of Virginia, 1977).

${ }^{47}$ Robert E. Wright, "Corporations and the Economic Growth and Development of the Antebellum Ohio River Valley," Ohio Valley History 9 (Winter 2009), 48-49.

${ }^{48}$ Royalty, "Banking, Politics, and the Commonwealth," 68.
} 
218,000 yards of cloth, fifth largest in the state. Adair and Green County produced 92,000 and 69,000 yards of cloth, respectively. ${ }^{49}$

Other manufacturing in the Green River reflected the natural strengths of the local economy. Widespread livestock raising led to the creation of many tanneries. During the 1810 s most of the counties south of the Green River had between three to five tanneries that produced roughly four thousand dollars worth of leather products in each county. Gunpowder mills also developed in these years. In 1812, Barren, Green, Grayson, Henderson, and Hopkins Counties all had one gunpowder mill. Barren County had the most diverse manufacturing in the region. In addition to tanneries and a gunpowder mill, it had a nail company and a paper mill. ${ }^{50}$ Demand for local manufactured goods grew steadily throughout the 1810 s and into the 1820 s. An early report on Kentucky industry noted that Barren County's paper mill and a newly developed furnace in Green County enjoyed "good demand." 51

As the region developed, small farmers reinvested the money received from trade into what historian Eugene Genovese terms "economically feasible and socially acceptable" ways - slavery and land. ${ }^{52}$ Increased access to market fueled the growth of slavery. A rising slave population coincided with improvements in river navigation between 1810 and 1820. In 1810, Barren County had 1,724 slaves; a decade later it had 2,446. Warren County experienced similar growth in its enslaved population. In 1810 , there were 1,498 slaves in the county; ten years later there were 2,554 . Counties situated

\footnotetext{
49 "A Statement of the Arts and Manufactures of the United States of America prepared by Secretary of the Treasury Albert Gallatin," Mar. 19, 1812, 121-29, Green River Research Collection, WKU.

${ }^{50}$ Ibid.

51 "Digest of Accounts of Manufacturing Establishments in the U.S.," Mar. 20, 1822, Green River Research Collection, WKU.

${ }^{52}$ Eugene D. Genovese, The Political Economy of Slavery: Studies in the Economy and Society of the Slave South, $2^{\text {nd }}$ ed. (1965; Hanover, N.H.: Wesleyan, 1989), 22-23.
} 
on waterways saw faster growth in the slave population. Green and Logan Counties, located near the Green and Barren Rivers more than doubled their enslaved population between 1810 and 1820. In Green County, the slave population rose from 1,401 to 3,261, while in Logan it nearly doubled from 2,486 to 4,698 . Counties less affected by river navigation experienced smaller slave population growth. In Grayson County, with limited access to the Barren River, the slave population grew from just over a hundred slaves in 1800 , to 184 in $1820 .^{53}$

Before 1820 , slave ownership was not concentrated in the hands of the planter elite. Instead, hundreds of small farmers purchased slaves for the first time and entered the slaveholding class. In 1800, only twenty-three of Muhlenberg County's 252 households (or 9 percent) had slaves. In 1825, almost 20 percent of the county's households owned slaves. Barren County began with higher numbers of slave owners. Twenty percent of Barren County households possessed slaves in 1800. By 1825, 32.5 percent did. Logan County saw the largest increases in slave ownership. In 1792, 15.6 percent of the county's households owned slaves. By 1810, that number doubled to 30 percent of households; ten year later, 43.7 percent owned slaves. ${ }^{54}$

Banking became an issue for Green River residents again during the 1814-1815 Kentucky legislative session. Distrust of the Bank of Kentucky grew throughout the state in the 1810s. Some politicians feared it had become too powerful and others resented that the bank favored merchants over farmers and manufacturers in its lending practices. Those without access to capital proposed chartering a new bank independent of the state to break the Bank of Kentucky's "monopoly." Green River politicians overwhelmingly

${ }^{53}$ U.S. Population Census 1810 and 1820, University of Virginia Library, http://mapserver.lib.virginia.edu/. ${ }^{54}$ Aron, How the West Was Lost, 206. 
supported the democratization of the state's banking system and in 1818 voted to charter forty-six independent banks, eleven of which were located in the Green River. ${ }^{55}$ The new banks fared poorly because of a lack of capital. Within a year many were beginning to collapse, with deleterious consequences for the Green River's small farmers. Their fears of banks seemed realized when the value of the banks' notes declined in value. Many small farmers found themselves in a position similar to that of Ben Helm of Logan County. In 1819, he held several notes of one of the failed banks. With the value of the notes falling, he tried to get rid of them quickly, "afraid to hold any of the Independent bank paper." Helm entrusted the notes to a friend whom he instructed to pay off a debt with it "if [the creditor] will receive it." "If not," Helm instructed, "do the best you can with it for me." $\$ 56$

The failure of the independent banks had important political repercussions. Green River Democrats declined in popularity. Already damaged for their failure to protect farmers, the Democrats about face on banks undermined their support among small farmers. In 1816, a "Friend to Genius" published a satirical play in a Danville paper that mocked the Green River politicians' abandonment of anti-bank politics. One part of the play, entitled "Logrolling, or Give and Take," focused on the private discussions of two Kentucky state representatives. The first speaker, who represented the Green River, asked the second for help to create a new county. The second speaker replied, "Have we not enough and more than enough?" "No matter for that," responded the Green River representative, "lend me a vote now and I will lend you one another time." The Green River politician is later asked to support more independent banks in the Green River.

${ }^{55}$ Royalty, "Banking, Politics, and the Commonwealth," 166, 186.

${ }^{56}$ Quotes from Ben Helm to Presley Edwards, Aug. 26, 1819, WKU; also see David W. Fairleigh to Harold H. Helm, Sept. 20, 1949, WKU. 
"Why that's a tough business," noted the Green River legislator, "my constituents are opposed to them." "Can't you excuse yourself," asserted the second politician, "by telling them the bank of Kentucky is an overgrown, aristocratical institution? And if that won't do, all you have to say is that it is a federal bank and was supported by Federalists." 57

But despite their problems, a few Democrats continued to enjoy political success. David Walker represented the region in the 1810 s and $1820 \mathrm{~s}$. Walker was undoubtedly aided by his humble beginnings which helped win the support of small farmers. Born in Virginia in 1760 , Walker fought in the Revolutionary War as a private, and like many of his constituents, earned two hundred acres of Green River land. After migrating to the region, he became active in politics and was elected to the state House of Representatives from 1793 to 1796 . By 1810 , Democrats like Walker faced more competition from politicians who supported the internal improvements upon which small farmers increasingly relied. Instead of taking a stance on this issue, Democrats like Walker reminded voters of their past achievements, particularly on the issue of land. In the 1817 congressional election, Walker urged voters to recall he "fought thro' the revolutionary war for your liberty." He reminded his constituents that "in '96 [he] opposed the selling of the vacant land south of Green River and in '97 advocated giving all the vacant land south of Green River to the poorer part of the community." "In 1809," he continued, he had "used his utmost exertions to have the headright law so amended as more effectually to secure the actual settlers, and obtain further indulgence for the payment of the State price." The political strategy worked, and Walker was elected to the U.S. Congress. ${ }^{58}$

${ }^{57}$ [Danville] The People's Friend, Jan. 30, 1819.

${ }^{58}$ David Walker to the Voters of the Sixth Congressional District, July 28, 1816, WKU. 
Political and economic changes after 1800 transformed the Green River. By 1820 , it was no longer an isolated region. Green River politicians led by Felix Grundy once fought against the spreading of the Bluegrass system of banks to the region. In the 1810s, however, Green River politicians reversed their position and the region received its first bank in 1807. Small farmers eagerly embraced and participated in the expansion of commerce internal improvements brought to the region, but the Democratic spirit influenced their attitude toward banking and they avoided banks for much of the $1800 \mathrm{~s}$. While the bank did not provide capital to finance internal improvements, it enabled Green River merchants to promote internal improvements, especially clearing the Green and Barren Rivers to make them more suitable for boats and increase farmers' access to markets. As the call for internal improvements grew, Democrats' popularity declined. After the $1820 \mathrm{~s}$, merchants became more organized and demanded enlarged internal improvements in an effort to make the Green River economically competitive with the Bluegrass. 


\section{CHAPTER THREE}

\section{TRANSFORMATION OF THE GREEN RIVER: BANKING, POLITICS, AND INTERNAL IMPROVEMENTS}

1820-1850

The decline of Green River's Democratic Party gave rise to politicians who supported expanding commerce and paved the way for the foundation of the region's Whig Party. Small farmers responded to improvements in river navigation by transporting goods to New Orleans. In the 1820 s and 1830 s, local elites lobbied county governments for more internal improvements, hoping to make the region's rivers suitable for steamboat navigation. After 1830, the number of banks in the region grew and played a larger role in fostering economic development than they had in the early nineteenth century. Most major Green River towns like Bowling Green, Greensburg, and Russellville had a branch of the Bank of the Kentucky which provided capital for merchants to expand their operations as well as fund local internal improvements. As the transportation infrastructure developed and farmers produced more for market, the Democrats' political rallying call of land ownership lost its appeal. After 1820, Green River politicians who supported expanded commerce and protective tariffs earned the votes of small farmers who believed they could benefit from banks and internal improvements in the Green River. The region's voters embraced the Whig ideology and supported the party in the 1830 s and 1840 s. 
The early internal improvement projects spearheaded by the region's merchants significantly influenced small farmers' market behavior. Transportation improvements were well received by farmers and they utilized the new outlets for trade in a variety of ways. Farmers far from water or who produced insufficient quantities of crops to justify building a flatboat made agreements with neighboring planters to transport their goods. Levels of formality differed with individual planters, but most agreed to market small farmers' crops for the highest price possible. In 1817, Sally Smith decided to sell planter George Young a hogshead of tobacco that he marketed with his own crops in New Orleans. "Received of Sally Smith," the agreement read, "1 hogshead of tobacco [which] I promise to freight to New Orleans for one dollar per hundred weight and sell [said] tobacco to the best advantage for S. Smith."1

Other farmers chose to circumvent the traditional planter-yeomen relationship and entrusted their crops to shipping firms that specifically marketed to yeomen, attesting to their interest in the market. As early as the 1820 s, shippers placed ads in local newspapers encouraging farmers to send their goods to New Orleans with them. "To the Farmers of Warren and Adjacent Counties," proclaimed one ad, "the subscribers have formed a partnership for the purpose of freighting tobacco and other produce from Big Barren River to the port of New Orleans." To entice small farmers further, the subscriber noted that "should farmers wish to have a small advance on each [hogshead] they ship, they can be accommodated."2 Other shipping firms promised similar advances to small farmers. R. R. O'Hara and Son of Lyon County, who shipped tobacco exclusively for small farmers, advertised, "We will make liberal advances in cash on tobacco or other

\footnotetext{
${ }^{1}$ Receipt from George Young to Sally Smith, Feb. 8, 1817, Young Family Papers, Kentucky Library, Western Kentucky University, Bowling Green, Kentucky (hereafter WKU).

${ }^{2}$ [Bowling Green] Spirit of the Times, Dec. 16, 1826.
} 
produce which may be delivered to us for shipments to New Orleans or other markets."” Several ads that appeared in the Bowling Green Spirit of the Times revealed that farmers also had the option to purchase flatboats. The subscribers promised to sell flatboats "at reasonable rates" to farmers who wanted to take their produce to New Orleans. ${ }^{4}$

Most of the goods loaded on to flatboats in the Green River were bound for New Orleans, where farmers found a vast market for their produce. Green River farmers participated in a global economy. Goods that arrived in New Orleans-most commonly surplus foodstuffs, livestock, and tobacco-were distributed to other parts of the United States and to countries like England where demand for tobacco was high after 1820. Traveler Betsy Taliaferro arrived in New Orleans with her husband in the 1830s and was awestruck by the size of the city's port and the capacity of its shipping. She considered it to be the "mart of the world" with "more shipping in port than scarcely ever has been seen here." "The Crescent City presents for miles shipping and steamboats, six and seven abreast," she recorded in her journal. She passed "flat boats by hundreds" that had traveled down the Mississippi River, and witnessed the transfer of their goods to nearby oceangoing brigs and schooners that transported the produce overseas. ${ }^{5}$

Flatboats were the primary way farmers transported goods to market, but the limited space and unreliability of the vessels limited economic growth. In the $1820 \mathrm{~s}$, local merchants sought additional river improvements to allow steamboat traffic from the Mississippi and Ohio Rivers to enter the Green River region through the Barren and Green Rivers. Bowling Green politician and merchant James Rumsey Skiles led this

\footnotetext{
${ }^{3}$ R. R. O'Hara Shipping Receipt, Feb. 23, 1842, O'Hara Records, WKU.

${ }^{4}$ Excerpt from "Story of Bowling Green and $1^{\text {st }}$ Presley Church," undated, Green River Research Collection, WKU.

${ }^{5}$ Betsy Taliaferro Diary, entries for Mar. 23, 28, 1839, Taliaferro Collection, WKU.
} 
push. Skiles inherited a general store from his father Jacob, who migrated to the Green River in 1803 from Virginia. When Jacob died in 1816, he left Skiles a successful business worth over ten thousand dollars and twenty thousand acres of land. Skiles realized the difficulty he and his fellow merchants had receiving merchandise from suppliers. Any goods shipped into the region had to travel across makeshift roads that became unreliable during the wetter months of the year and caused costly delays. To Skiles the solution was clear: enlarge the region's natural waterways for steamboats to pass through. ${ }^{6}$ Many of Skiles's contemporaries supported this goal, including the editor of the Bowling Green Spirit of the Times. In 1827, he argued that if further river improvements were not enacted the town's economy would stagnate. A "market must be created; otherwise we can never be independent or prosperous," he reminded his readers. "We can clear out our rivers," he wrote, "and make them navigable every season of the year. We, the people of Warren [County], can bring steamboats to our doors."7 Skiles did exactly that.

In January 1828, James Garrett Pitts, Skiles's business partner and captain of the steamboat the United States, sailed his boat to the closest landing outside Bowling Green loaded with goods. The event was a publicity stunt organized by Skiles and Pitts to rally farmers' support for expanded river projects and demonstrate that steamboats were faster, safer, and could transport more goods than flatboats. The display had its intended effect. One farmer watching workers unload the steamboat could not believe that "such an

${ }^{6}$ Helen Bartter Crocker, The Green River of Kentucky (Lexington: The University Press of Kentucky, 1976), 11.

${ }^{7}$ [Bowling Green] Spirit of the Times, Feb. 17, 1827. 
amount of goods could ever be consumed." ${ }^{\prime 8}$ Pitts also offered free rides on his steamboat. In all, about thirty young men from Bowling Green, including Henry Fox, took him up on the offer. Fox recalled that Pitts "landed us at Morgantown," a small town north of Bowling Green where the Barren and Green Rivers meet. "The next morning we put out at daylight and footed it home; and if you ever saw a worn out set, we were." According to Fox, Pitts could not return the men to Bowling Green because "the river was so high, he couldn't land."9

Despite the group's experience, the advantages of steamboats over flatboats were apparent and by 1830 Skiles and other merchants had enough support to form the Green and Barren River Navigation Company. Led by local elites, the company sought to bring steamboat traffic to the Green River by constructing "suitable locks, dams, docks, basins, canals, chutes and slopes, upon Green River and its tributary streams with a view to render them permanently navigable." Skiles believed that the company's initial costs would be recouped by its right to "demand and receive" tolls at a series of locks constructed along the river. The company's directors attempted to raise sixty thousand dollars worth of stock for the company, fifteen thousand of which was provided by the state government. At one hundred dollars a share Skiles and his associates sought the financial support of the region's planters and merchants; small farmers could not afford to invest in the company. ${ }^{10}$

Skiles could not depend on local banks for investment capital. By the mid-1820s, most of them were near bankruptcy. The Bank of Kentucky began strong, but its

\footnotetext{
${ }^{8}$ Helen Bartter Crocker, "Steamboats for Bowling Green," The Filson Club History Quarterly 46 (Jan. 1972), 12.

9 "Recollections of Henry Fox," typescript, Green River Research Collection, WKU.

${ }^{10}$ Acts Passed at the First Session of the Thirty-Eight General Assembly for the Commonwealth of Kentucky (Frankfort, 1830), 225-26.
} 
business faltered after the Napoleonic Wars. The forty-two independent banks chartered in 1818 fared even worse and hardly made an impact on the state's economy. The independent banks' charters allowed them to issue notes three times the amount of specie they held in reserve. To protect against a run on their specie the notes of the independent banks could be redeemed at the Bank of Kentucky. However, when the Bank of Kentucky notes became almost as undesirable as those of the independent banks the provision provided little protection. The legislature revoked the bank's charter in 1822 . In 1821, it chartered the Bank of the Commonwealth, a collaboration between private and state interests, to expand banking in Kentucky. The bank had several branches in the Green River, including Bowling Green and Greensville. However, the bank was no more successful than previous institutions. In 1830 , it decided to close every unprofitable branch; soon all its branches had closed. Between the 1820 s to 1830 s, banks in the state were weak and played an insignificant role in the economic development of the Green River."

The one hundred dollar stock price prevented small farmers from investing in the Green and Barren River Navigation Company and Skiles could not garner sufficient support from planters and merchants. The company lowered the initial stock offering to forty-five thousand dollars. In an effort to demonstrate his faith in the company, Skiles invested a considerable amount of his money in the business and purchased two "steam merchant mills" worth seven thousand dollars. When this proved unsuccessful, he went to the state government to secure funding. As a former politician, Skiles had considerable political influence and secured state funds to pay for a survey of the river in 1833 and the initial construction costs in 1834 . Skiles gained a more significant victory

${ }^{11}$ Basil W. Duke, History of the Bank of Kentucky 1792-1895 (1895; New York: Arno Press, 1980), 16-21. 
the following year when the state created a board of internal improvements and appointed Skiles and fellow navigation company director, James T. Morehead, to the board. As a result, they were able to direct considerable state funds to their navigation company. ${ }^{12}$

To survey lands along the river, Skiles and his associates relied on eastern engineers who had experience building canals in Ohio and Pennsylvania. Skiles also hired surveyors from eastern states to map the Green and Barren Rivers. "I have been through some very rough places along the river," wrote one surveyor to his family in Ohio. His team surveyed the Green River to "the mouth of the Big Barren-a branch of the Green River-and up to the head of the steam" for the purpose of discerning "the practicality of steamboat navigation." ${ }^{\prime 13}$ After the survey was complete, construction began the following year on locks and dams one and two, financed by the state which allotted fifty thousand dollars for their completion. ${ }^{14}$

However, slow progress sparked tension between the company and the state improvement board. Errors in the company's cost estimates undermined its credibility. In 1833, Skiles hired Pennsylvanian canal engineer Abner Lacock to determine initial costs and oversee construction. Lacock believed the project could be accomplished for sixty-nine thousand dollars. For an additional thirty thousand the canal could be extended all the way to Bowling Green, for a total cost of roughly $\$ 733$ per mile. The state board was skeptical that the project could be completed at this cost, but decided to fund it nonetheless. Factors other than costs also slowed progress on the works. In 1835, as lock and dam two neared completion, a cholera epidemic killed several workers. To complicate matters, the rivers frequently flooded during construction, forcing overseers to

${ }^{12}$ Crocker, "Steamboats for Bowling Green," 14.

${ }^{13}$ Franklin Mills to H. Brown, Sept. 4, 1836, WKU.

${ }^{14}$ Crocker, The Green River of Kentucky, 17. 
lay off workers until it was dry enough to continue. This led to additional problems. The local farmers hired had little desire to return to work once they arrived home. Skiles noted the irregularity of the work force in his report to the state board of internal improvements. "Laborers have been scarce throughout their whole progress," he lamented, "being drawn principally from the neighborhood, and subject to be called off to agricultural pursuits, at the most important seasons of the year." 15

In Frankfort, Skiles received help from his uncle, Senator Joseph Rogers Underwood, also from Bowling Green. Underwood supported internal improvements and like his nephew frequently urged the state to support improved navigation on the Green River. "I have made four speeches in relation to the public land and internal improvements," he wrote to his wife Elizabeth Underwood. "In making this speech tears burst from my eyes with excitement and I saw several Senators who seemed to feel as much as I did." Along with Skiles, Underwood was instrumental in allocating state funds for sustained improvements on the Barren and Green Rivers. ${ }^{16}$

Politicians like Underwood owed their rise to the region's early merchants who pushed for river improvements and successfully integrated small farmers into an expanding marketplace. The drive for improvements eroded support for the Democratic Party and built political support for future Whigs like Underwood. Underwood embodied this economic and political transition and garnered substantial support from the region's voters. Underwood's early life was similar to Grundy's. He was born in Virginia to a wealthy family and migrated to Kentucky at an early age. In 1803, he moved to Barren County to live with his uncle, Edmund Rogers. After graduating from Transylvania

${ }^{15}$ Ibid; James R. Skiles to James T. Morehead, Dec. 2, 1839, Green River Research Collection, WKU. ${ }^{16}$ Nancy L. Priest, "Joseph Rogers Underwood: Nineteenth Century Kentucky Orator," Register of the Kentucky Historical Society 75 (Oct. 1977), 298-99. 
University in 1811, Underwood enlisted to fight in the War of 1812. Returning home, he worked as a lawyer until 1816 when he was elected to represent Barren County in the state legislature. In 1823, he moved to Warren County and established himself in Bowling Green where he enjoyed continued political success and voters elected him to serve in the state legislature. In 1835, Underwood was elected to the U.S. House of Representatives on the Whig ticket, a seat he held until $1843 .^{17}$

On the stump, Underwood presented himself as a refined gentleman. Historian J. B. Morton described him as possessing "all the graces of the old-time Kentucky gentleman, urbane of manner, with a tender heart, a keen sense of humor, eloquent on the stump, a successful lawyer, a profound statesman, and a pioneer soldier." Underwood also distrusted the Democratic Party whom he believed full of "knaves" who misled the men into electing people like Andrew Jackson to office. Their political tactics, he maintained, consisted of "exciting the feelings of the people" which "had its effect with the unthinking."18

Underwood shared many of his voters' views on slavery which added to his popularity. He later reversed his stand on slavery and became an emancipationist, but between 1816 and the 1840 s he defended the institution and supported slaveholders' property rights. In an address to Congress, he identified himself as a slaveholder. "I was born among slaveholders," he said, "was educated by one, have lived all my life in their midst, and I have been honored by them with many important offices." In 1837, as a representative in the U.S. House, he attacked Massachusetts voters for petitioning to end slavery in the District of Columbia. He also proposed legislation that strengthened the

${ }^{17}$ Ibid., 287.

${ }^{18}$ J .B. Morton, quoted in, ibid., 288, 291 
current Fugitive Slave Law by imposing "a duty upon the government to establish a system by which fugitives can be reclaimed." If the government was unable to return the fugitive slave, Underwood proposed that the owner of the slave receive "from the government, the value of that slave, under the supposition that the government has been derelict in the performance of its duties." 19

Green River politicians like Underwood extolled the virtues of internal improvements and slavery and helped form the Whig Party in the 1830s. The Whig political philosophy contrasted sharply with the Democratic Party's. Most southern Democrats celebrated an agrarian society dominated by small farmers and limited market involvement, while Whigs wanted to expand markets, modernize and expand the country's banking system, and develop internal improvements. Henry Clay, the leader of Kentucky's Whigs, outlined the party's goals in his "American System":

A sound national currency, regulated by the will and authority of the nation. An adequate revenue, with fair protection to American Industry. Just restraints on the executive power, embracing a further restriction on the exercise of the veto. A faithful administration of the public domain, with an equitable distribution of the proceeds of sales of it among all the states. An honest and economical administration of the General Government, leaving public offices perfect freedom of thought and of the right of Suffrage, but with suitable restraints against improper interference in the elections. An amendment of the Constitution, limiting the incumbent of the Presidential office to a single term. ${ }^{20}$

${ }^{19}$ Ibid., 294-96.

${ }^{20}$ Henry Clay to Jacob Strattan, Sept. 13, 1842, WKU. 
By the 1830s, the Green River solidly supported the Whigs and clubs formed throughout the region to demonstrate support for the party. In 1840, Russellville Whigs formed the Tippecanoe Club in honor of Whig presidential candidate William Henry Harrison. ${ }^{21}$ Green River Whigs helped shape Whig policy at the state level. In 1835 , the party called a convention in Frankfort to discuss political strategy and elect representatives for governor and lieutenant governor. Green River Whigs requested a postponement because the date, August 14, 1835, was "not sensible." "It will interfere with many of the courts," they stated, "and is too soon after the [local] election." Whig politicians from northern Kentucky and the Bluegrass did not want to wait for their Green River colleagues and attempted to convene in August. Green River Whigs and Whigfriendly newspapers in the region called the decision "highly uncourteous." They warned their fellow Whigs of future repercussions should they again be excluded from important political discussions and reminded them that the support of "Green River friends" was crucial for Whig victory in the state. "If the Whigs in the coming elections wish for harmony and concensus," they concluded, "they should not disregard the wishes of the Green River Whigs., 22

The Whig message resonated loudest with merchants residing in urban centers, but it also found an audience among small farmers in the Green River who by the 1830s used the waterways for commercial exchanges. Whigs argued that tariffs on British imports would ensure that planters and farmers had a market for home-produced goods. ${ }^{23}$

\footnotetext{
${ }^{21}$ Henry Clay to Henry Henion, Sept. 5, 1840, WKU.

${ }^{22}$ Letter from "Whig" to "the Commonwealth," June 1, 1835, Filson Historical Society, Louisville, Kentucky (hereafter FHS).

${ }^{23}$ Charles Grier Sellers, Jr. "Who Were the Southern Whigs?" The American Historical Review 59 (Jan. 1954), 335-46; also see John R. Van Atta "Western Lands and the Political Economy of Henry Clay's American System, 1819-1832," Journal of the Early Republic 21 (Winter 2001), 633-65.
} 
Green River politicians like Underwood quickly incorporated tariffs into their political speeches and emphasized how they helped maintain small farmers' competency. Green River Whigs referred to tariffs frequently in their speeches and articles. Leading Whigs told the "voters of Warren County" that "the Whigs are the advocates of an AMERICAN Tariff." Tariffs, they argued, made farmers economically independent because they saved them from becoming "slaves" to European markets. "If we abandon our tariffs," they told voters, "Europe dictates to us all our laws on all the greatest subjects of manufacturers, commerce and trade." To prevent small farmers from becoming "paupers of Europe," Whigs advocated "adequate protection of American industry" by "discriminating the amount of duty imposed between those articles which the American citizen can manufacture or produce and those which they can not." Whigs promised that tariffs would afford "a certain market to the American farmer for the production of the soil at [increased] prices." 24 Without tariffs, the argument went, farmers became dependent on-or "slaves" to-European markets that dictated what crops farmers grew and what prices they received. The language was carefully chosen to alarm slaveholding farmers. Underwood also stressed that tariffs were vital to the "national defense." Tariffs along with the Green River's "many rivers and fertile land," would enable its farmers to achieve "independence from the dictates of Europe." 25

Most yeoman farmers appeared to embrace this rhetoric. Farmer William Blackburn of Allen County relied on the river to transport goods to market. He also enjoyed the benefits increased commerce brought to his community. "Money is a scarce article here," he wrote his brother, "though a little plentier [sic] now than for some time

${ }^{24}$ The Voters of Warren County Whig pamphlet, 1844, WKU.

${ }^{25}$ Ibid. 
past [since] the tobacco [shipped] from Drakes Creek to Bowling Green, for the tobacco that went on flat boats have brought back $\$ 30,000$." Blackburn's complaints about England's high tariffs on American products mirrored those of the Whig Party. "Were it not for the high duty paid on [tobacco] in the foreign market," he continued, "the people here could do well by raising it." Tariffs on English products, Blackburn believed, were the only means to protect the price of American goods. "Oh! Shame on the statesman [who] allows [England] to flood our nation with their luxuries without imposing countervailing duties on their articles." Until politicians fought for protective tariffs at home, Blackburn concluded, "shame" was the only "article . . Kentucky" would export. $^{26}$

Few yeomen left statements similar to Blackburn's. However, the absence of historical records detailing small farmers flatboating it to New Orleans does not reflect an absence of farmers' market activity but a scarcity of yeomen records and diaries. By the time Whigs rose to power in the Green River most farmers were integrated into the market and transported their goods to New Orleans by flatboat or entrusted them to a local planter to sell. Surviving records reveal that yeomen depended on planters to market their crops for them. After inspecting O. Felders's pork, Willis Green purchased eighty-two pounds and loaded it on a boat to New Orleans to sell with his own cargo. ${ }^{27}$ In 1835, Green made a similar agreement with farmer Miles Vamarts, purchasing a "boat load" of his surplus peas and shipping them to New Orleans for sale. ${ }^{28}$ Such practices also underscore the predominance of shippers such as Henry Fox who transported goods to market.

\footnotetext{
${ }^{26}$ A. Billingsley to William Blackburn, July 28,1844 , WKU.

${ }^{27}$ Receipt from J. Rorans, May 27, 1832, Willis Green Papers, FHS.

${ }^{28}$ Receipt from Willis Green, May 9, 1835, Willis Green Papers, FHS.
} 
The records of the South Union Shakers shed light on the market involvement of small farmers. Shakers made several trips to New Orleans on flatboats throughout the $1820 \mathrm{~s}$ and $1830 \mathrm{~s}$ and the journal of one of these voyages survives, revealing the thriving river trade. On Tuesday, July 11, 1831, Thomas Shannon and three Shaker crew members departed from South Union headed to New Orleans. On board they had "garden seed, jeans, lindsey, straw hats, sage, thyme, apples, and cider." They travelled up the Green to the Ohio River, then southward, regularly stopping at river towns to "see if there was any chance for selling some of our articles." Their most plentiful item for sale was garden seed that they brought "with the expectation of receiving the proceeds for the seed left last year, but in this we were disappointed." After arriving in New Orleans, they sold the seeds, herbs, and hats not sold on the voyage. They also purchased sugar, coffee, tea, mackerel, tanner's oil for curing hides, and a set of silver spoons for one of the elders, and secured passage back home aboard the steamboat The Kentuckian. ${ }^{29}$ Whigs also supported re-chartering of Bank of Kentucky in 1834. The new bank was organized like its earlier namesake, consisting of branch banks throughout the state, with the principal branch in Louisville. In the Green River, the bank had branches in Greensburg, Bowling Green, and Hopkinsville. Eleven directors operated the bank. Three of the directors were picked by the governor or recommended by the Senate; private stockholders elected the remainder. The bank held a capital stock of five million dollars, two million of which was held by the state and the rest purchased by individuals

\footnotetext{
${ }^{29}$ Thomas Shannon Journal, entry for July 11, 1831, WKU.
} 
and companies. Shares in the bank were one hundred dollars each, ensuring that most small farmers did not own stock. ${ }^{30}$

The bank soon demonstrated its worth, helping to fund river improvements in the Green River. By 1837, the state had loaned one hundred and forty thousand dollars to the Green and Barren River Navigation Company, more than any other internal improvement project in the state, to finish the last three locks and dams. The national economic crisis of 1837 crippled the ability of Kentucky's board of internal improvements to provide funds to complete the project. The next year, members of the state board toured the works and found it only half completed. With too much invested in the project to back out, the state sold bonds at high interest rates, borrowed two hundred thousand dollars from the Bank of Kentucky, and diverted funds set aside for education. Consequently, the internal improvements board charged Skiles with mishandling state funds and removed him as chairman of the company. The state also assumed direct control of the project's finances. ${ }^{31}$

Small farmers enjoyed few direct benefits from the expansion of banking. Bank loans helped the sons of some small farmers become first time landowners when they moved out on their own and started families. They believed that they would produce a large enough surplus to sell at market and pay off the loan. However, farmers often faced problems that undermined their ability to repay. An unusual dry spell, pests, or labor shortages could substantially reduce the size of a crop. As a result, during the 1810 s and 1820s many small farmers became indebted to banks and had little hope of repaying the money. In 1825, Underwood noted in his journal that "credit and securityships [sic] have

\footnotetext{
${ }^{30}$ Bank of Kentucky Charter, Jan. 17, 1835, Hines Family Papers, WKU; Duke, History of the Bank of Kentucky, 23-27.

${ }^{31}$ Duke, History of the Bank of Kentucky, 23-27.
} 
during the last eight years devastated the fortunes of thousands and left them in wretchedness. No one ought to become responsible for another where the object is speculation: in other words where the ability to pay depends on the profit to be made out of the money borrowed or property purchased.",32

Farmer Jeremiah Frazier lost his farm because of his inability to pay his debt. Frazier was a typical Barren County yeomen farmer. There is no evidence that he owned any slaves but he may have occasionally rented them. In 1832, he borrowed money from the bank and purchased a farm where he lived with his wife and four sons. He grew oats, corn, and wheat, and raised hogs. He did not produce market-oriented crops like tobacco which may have contributed to his financial problems. He soon he fell behind on his payments to the bank. The bank's attempts to recover their funds instilled in Frazier a distrust for banking. "I feel very confident," he wrote to his brother that, "if banking is encouraged either by Congress or state legislatures and circulated to much extent, it will always be attended with danger." Unable to repay the debt, Frazier sold everything to satisfy the bank and moved his family to Tennessee. "I moved in December," Frazier wrote, "having been injured very much having to pay debts to men that were as void of principle as human beings are capable of being." "I have paid for men who are now beginning in society which has caused me to lose upwards of $\$ 1,500 ., 33$

Other Green River residents welcomed banks to the region. Many recognized that without the investment capital provided by the Bank of Kentucky in 1837 the Green and Barren Rivers project could have failed. Whig politician Robert W. Lucas noted that banks made internal improvements possible. "It is folly for [the legislature] to restrict

\footnotetext{
32 Joseph Rogers Underwood Diary, entry for Nov. 2, 1825, Underwood Family Papers, WKU.

${ }^{33}$ Jeremiah Frazier to James Frazier, May 13 and Sept. 7 1832, Frazier Papers, WKU.
} 
[banks]," he wrote. "So much is due them from the citizens of the state that it would be unwise to force the banks in anyway." Lucas believed banks were one of the essential foundations of economic opportunity, and to regulate them would "oppress the people and bring ruin on them.".34

The final locks and dams were finished in 1842. Politicians and merchants were ecstatic that steamboats could now travel up and down the Barren and Green Rivers year round. Many citizens of Bowling Green noted the rapid growth of the city's economy after the arrival of steamboats. Lucas celebrated the changes. "Should we not rejoice as a people," he wrote, "who seemed by nature cut off from such speedy and fruitful navigation." "The applications of our [internal improvements] has succeeded beyond the most [sober] expectations. ${ }^{35}$ Steamboats richly "laden with all the comforts of life" became a common site for the people in town. "Steamboats coming to and departing from Bowling Green daily," Lucas noted in his journal, "which must make it ultimately a city." Lucas and many other citizens in Bowling Green believed that steamboats would allow the region to compete economically with other parts of the state. ${ }^{36}$ Once river improvements were completed, New Orleans tobacco exports grew significantly due to the Green River region's increased accessibility to southern markets.

However, the steamboat did little to diversify the economy or provide a base for expanded manufacturing, at least before the mid-1850s. ${ }^{37}$ Instead, river navigation reinforced the Green River's agrarian economy and reliance on staple crops, reflecting

\footnotetext{
${ }^{34}$ Robert Wilkins Lucas Journal, entry for Feb. 24, 1840, Lucas Collection, WKU.

${ }^{35}$ Ibid., Mar. 24, 1841, WKU.

${ }^{36}$ Ibid., Feb. 19, 1840, Feb. 17, 1842., WKU.

${ }^{37}$ For a discussion of a region where economic improvements did spark manufacturing, see A. Glenn Crothers, "Banks and Economic Development in Post-Revolutionary Northern Virginia, 1790-1812," The Business History Review 73 (Spring 1999), 1-39.
} 
the motivation of those who invested in internal improvements. Southern economic development relied on planters and merchants who owned a majority of their region's wealth. This was the case in the Green River where few if any small farmers could afford to purchase stock in Skiles's navigation company. Planters and merchants expected few dividends from their investment in such companies. Rather, they counted on the indirect benefits companies brought to their communities-increased land values and local commerce, and access to market and to consumer goods. ${ }^{38}$

The institution of slavery also limited the Green River's economic development. Slavery in general tended to create an economic imbalance by transferring most of a community's capital into the hands of slaveholding planters. Those who benefitted most from slavery heavily influenced, or directly controlled, local governments and used their capital investment to protect their economic welfare. In the Green River, the largest proponents of internal improvements were also planters and politicians or both. The one hundred dollar stock price of Skiles's navigation company prevented most small farmers from becoming shareholders even though they benefited from improvements to the region's waterways. Local elites, mostly wealthy slaveholding planters, became shareholders because they had the capital, produced the largest economies of scale, and stood to profit most from increased transportation. Improving the Green and Barren Rivers simultaneously reinforced the social hierarchy and the agrarian economy that depended on the slave labor they largely owned. ${ }^{39}$

\footnotetext{
${ }^{38}$ John Majewski, "Who Financed the Transportation Revolution? Regional Divergence and Internal Improvements in Antebellum Pennsylvania and Virginia," The Journal of Economic History 56 (Dec. 1996), 763-88.

${ }^{39}$ Kenneth L. Sokoloff and Stanley L. Engerman, "History Lessons: Institutions, Factor Endowments, and Paths of Development in the New World," Journal of Economic Perspectives 14 (Summer 2000), 217-32.
} 
Nevertheless, small farmers embraced this model of economic development and attempted to duplicate planters' success. ${ }^{40}$ They used slave labor, either rented or owned, and shifted crop production from subsistence crops, selling small surpluses at market, to market-oriented staples like tobacco and cotton. Unfortunately, records are fragmentary and it is difficult to determine when the transition occurred, but by the 1840 s small farmers were heavily invested in staple crops. In the 1840 s and 1850 s, tobacco production remained high throughout the Green River country, while subsistence crops production was relatively static. ${ }^{41}$

\footnotetext{
${ }^{40}$ James Oakes, The Ruling Race: A History of American Slaveholders (New York: W. W. Norton \& Company, 1998), 37-68.

${ }^{41}$ U.S. Agricultural Census 1840 and 1850, United States Census Office Online Archives, http://www.agcensus.usda.gov/Publications/Historical_Publications/index.asp.
} 
Figure 3: The Expansion of United States Tobacco Production by State, 1839-1859
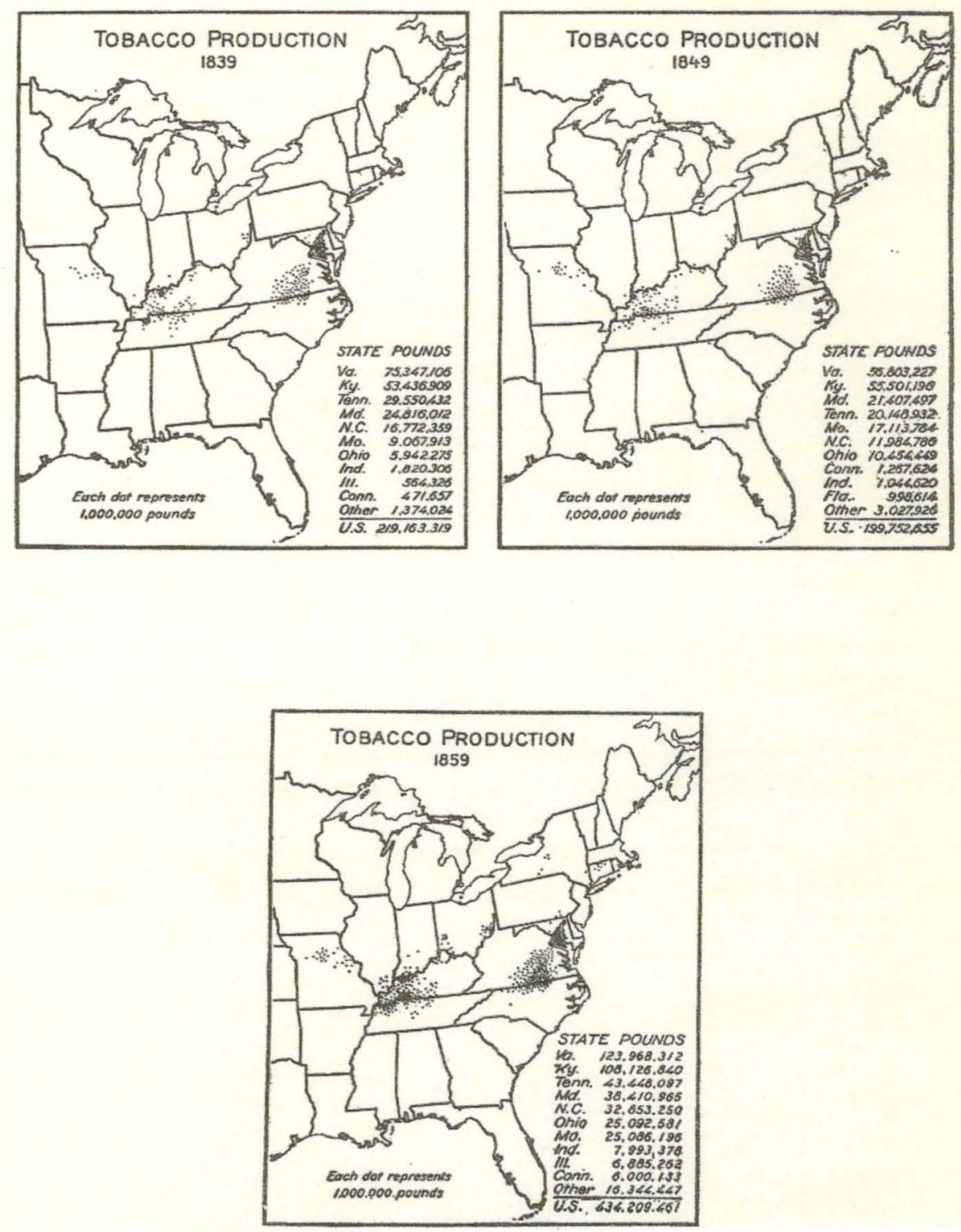

Source: Map from Lewis C. Gray, History of Agriculture, 2:759.

Steamboats on the Green River made it profitable for yeoman farmers to produce for market. By the $1840 \mathrm{~s}$, small farmers produced large quantities of tobacco with the aid of slave labor and transported it to New Orleans. Farmers grew great quantities of tobacco and transported it down river to meet foreign demand. The farmers of Todd 
County, in the southern part of the region, became heavy producers of tobacco, growing over three million pounds annually. Barren County farmers also grew large amounts of the crop-nearly two and a half million pounds in 1840 . Surrounding counties produced impressive quantities of tobacco in 1840 , including Green County which produced nearly two million pounds and Warren County which produced slightly over one and a half million pounds. Logan County experienced the fastest growth. In 1840, its farmers grew nearly four hundred thousand pounds of tobacco, but in 1850 they exported over two and a half million pounds (see Table 4). ${ }^{42}$

Steamboats transformed how many farmers transported their goods to market. Some farmers still used flatboats or relied on planters to market their crops, but increasing numbers delivered their goods directly to steamboats. This practice saved farmers time and expense and ended their dependence on planters. In 1847, the shipping manifest for the steamboat Glencol reveals the shift, listing small farmers' shipments of tobacco and corn destined for New Orleans. Of the nine shipments on board, seven contained between one and six hogsheads of tobacco. The remaining two contained eleven and twenty-nine hogsheads respectively. Also on board were "three packs of corn in dispute" and three wet hogsheads of tobacco. ${ }^{43}$

Farmers also increased their production of livestock, reflecting its rising value as commodity (see Table 3). Barren County led the Green River in production of livestock because the county's natural prairies could support large numbers of grazing animals. In 1840 , Barren County was among the top five counties in the state in livestock production, raising nearly eighteen thousand cattle and nearly twenty-five thousand sheep. Barren

\footnotetext{
${ }^{42}$ Ibid.

${ }^{43}$ Shipping receipt for Josiah Newman, July 5,1847 , WKU.
} 
County farmers also raised pigs in large numbers, nearly seventy thousand in 1840 .

Other Green River counties produced equally impressive numbers of livestock. In 1840, Warren County farmers raised more cattle than their Barren County counterparts, over thirty-four thousand, and only slightly less sheep (twenty-one thousand) and pigs (fiftytwo thousand). ${ }^{44}$

Internal improvements benefited Green River farmers, but for Skiles and the navigation company, financial problems continued. In 1846, the company faced increasing scrutiny from the state board of internal improvements. Many politicians argued that the Green River company had received favorable treatment from the state, pointing to the two million dollars it had invested in improvements in the company. As a result, agitation arose in "every sector of the state," as politicians claimed an equal right to expenditures from the state treasury. To complicate matters, revenue from the locks, which the local and state board believed would repay the costs of construction, hardly raised enough income for the maintenance of the locks and dams. The state board argued that canal tolls were too low and seized control of the project from the company. "If we cannot pay the interest in full on the investment," the state board concluded, "we may at least discharge a part of [the debt] and thereby relieve [the state] from an unequal burden." 45

${ }^{44}$ U.S. Agricultural Census 1840 and 1850, United States Census Office Online Archives, http://www.agcensus.usda.gov/Publications/Historical Publications/index.asp.

${ }^{45}$ Annual Report of the Board of Internal Improvement, Dec. 24, 1846, 473, Green River Research Collection, WKU. 
Figure 4: $\quad$ Statement of Tolls Received from Boats on Green and Barren River, 1846

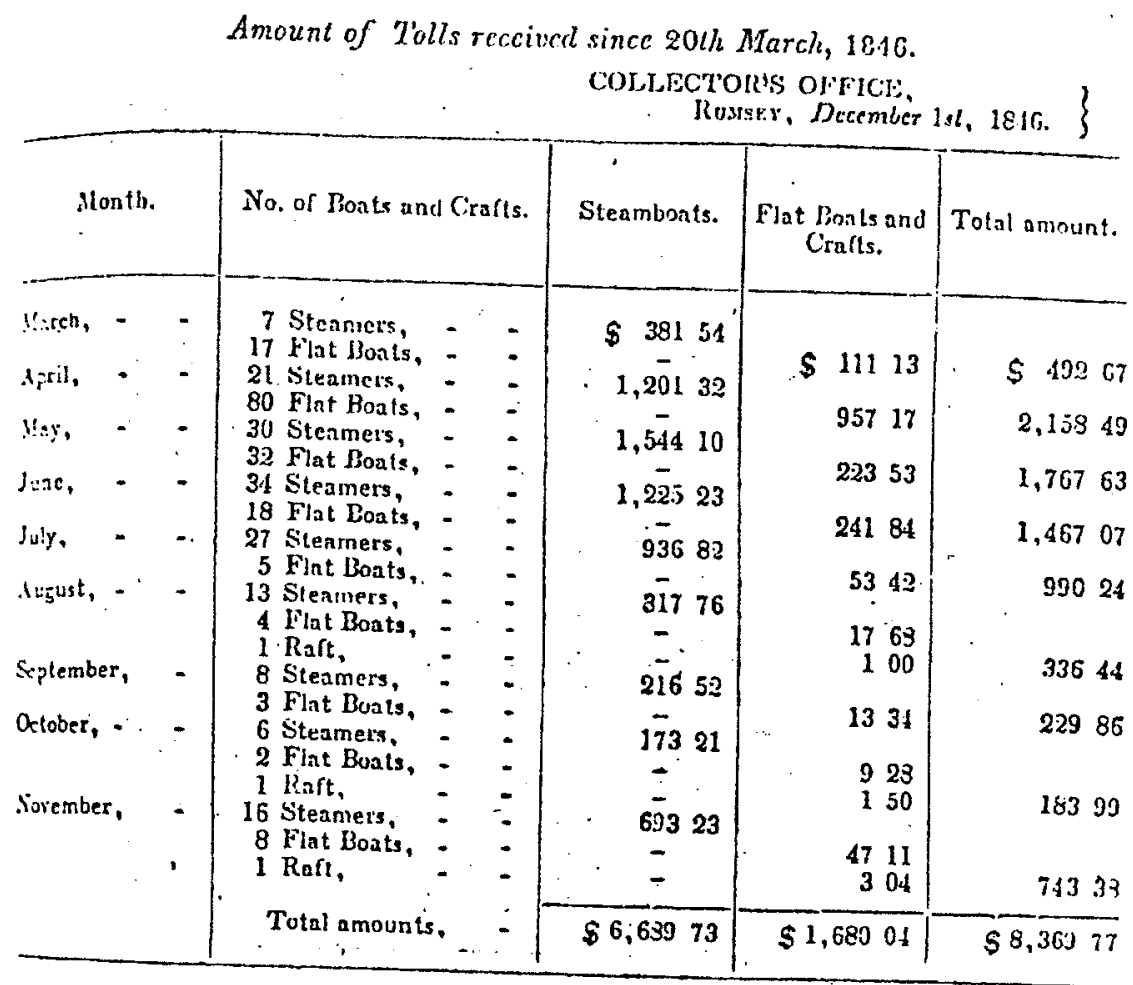

Source: Annual Report of the Board of Internal Improvements, Dec. 1, 1846, 507, Green River Research Collection, WKU.

Company directors were outraged by this move and feared the economic repercussions of raising tolls on the Green River. Higher fees, they argued, would decrease traffic from boats entering the Green River from the Ohio and Mississippi Rivers, "the fixed basis of nearly all the commercial operations of the State." Manufacturing industries in the Green River depended upon the rivers to get their goods to market. "Our hemp, bagging, rope, tobacco, grain, and hay, nearly all the products of our soil and industry," the company directors stressed, "first seek one of the rivers no matter for what destination. We are disconnected from the South by an immense space of rugged and mountainous country, so remote from the southern sea ports, that we cannot, 
by any line of improvement we can make, give that direction to any considerable portion of our business." ${ }^{46}$

Difficulties with internal improvements coincided with the decline of the Kentucky Whig Party. Problems began during Kentucky's 1849 constitutional convention as Whig gradual emancipationists led by Robert J. Breckinridge sought to end slavery in the state. Whigs split on the issue, enabling Democrats to win a majority of the seats at the convention. The convention also debated other constitutional reforms, including a measure to protect local governments from corruption by preventing certain offices from being purchased by the highest bidder. Whigs remained silent on this issue as it favored them, but Democrats successfully made it a public issue. Whigs attempted to avoid alienating their popular base by avoiding the issue altogether. But the political tide was turning against the Whigs and divisions within the party became evident at the local level. ${ }^{47}$

The troubles of the national Whig Party reflected its problems at the local level. The issue of slavery especially hurt Green River Whigs against a resurging Democratic Party that supported the institution. The rise of antislavery sentiment within the Whig Party undermined proslavery Whigs in the Green River. Warren Underwood noted the difficulties he faced in his 1849 election for the state senate against Democratic candidate Thomas Smith. "My competitor and myself both were of the pro-slavery party," Underwood wrote, "yet my brother [Joseph] R. Underwood [and] my kinsman Mr. A. C. Ducherson and several of the members of the convention that nominated me were Emancipationists and this caused my position and security to be suspected." Party

\footnotetext{
${ }^{46}$ Ibid., 474.

${ }^{47}$ Christopher Paine, "Kentucky Will be the Last to Give Up the Union," (Ph.D. Diss., University of Kentucky, 1998), 98-108.
} 
loyalists worked hard and increased voter turnout, winning Underwood the election by a narrow margin of only twenty-five votes. ${ }^{48}$

Small farmers' use and reliance on internal improvements showed no signs of slowing down in the 1850s. In his 1855 report to the state board of internal improvements, S. H. Murrell, superintendant of the company, reported that the Green River's "intelligent and enterprising farmers" were producing and shipping more on the rivers. "Never before in this country," he noted, "has so rich and bountiful a return been poured into the lap of the agriculturalist. The crops are unprecedently [sic] large [with] wheat, corn, tobacco, and pork in great abundance., ${ }^{, 49}$ Large numbers of small farmers, not just planters, used these internal improvements. The Stubbins and Pork House Company shipping logs of the late 1850s reveal that small farmers shipped a great deal of produce. Of the sixty-one orders received by the company between March 4, 1859 and June 30,1859 , thirty-nine were by small farmers. ${ }^{50}$

Internal improvements dramatically increased small farmers' market participation. Transportation improvements were first supported by merchants, but farmers quickly embraced them and shipped growing quantities of staples to southern markets. Economic development, in turn, transformed the politics of the region. In the first decades of the century farmers voted Democratic, but they switched to the Whigs when the party promised to expand market access on which farmers relied. Planters like Underwood also depended on the Green River's waterways and served as small farmers' representatives. They worked to secure crucial funding from the state government to

\footnotetext{
${ }^{48}$ Diary of Warren Underwood, entry for June 13,1850 , Green River Research Collection, WKU.

${ }^{49} \mathrm{~S}$. H. Murrell to the Kentucky Board of Internal Improvements, Nov. 1, 1855, Green River Research Collection, WKU.

${ }^{50}$ Stubbins and Lucas Pork House Log, entries for Mar. 4, 1859 to June 30, 1859, Green River Research Collection, WKU.
} 
complete the navigation projects in the region. Before the 1830s, banks had insufficient investment capital and played a limited role in the region's economic development. In 1837, however, the Bank of Kentucky helped finance construction on the Green and Barren Rivers. The internal improvement projects never became self-sustaining and the financial burden of repairing locks and dams undermined the company's profit. But between 1820 and the 1850 s farmers relied on the system and embraced the economic transformation it wrought. 


\section{CONCLUSION}

This thesis argues that small farmers participated in the market economy to secure their economic independence. This claim contradicts claims of Eugene Genovese and more recent historians like Steven Hahn who argue small farmers resisted market expansion and only entered the market when forced.' ${ }^{\prime}$ This thesis demonstrates that small farmers' economic behavior changed over time and was more complex than most historians have argued. In 1790, the Green River's small farmers used the market to secure economic security. By 1850 , they had become fully integrated in the market and emulated planters' pursuit of profit. $^{2}$

The development of Kentucky's Green River from 1790 to 1850 provides an excellent opportunity to study the economic lives of small farmers. By 1850 , the economic and political changes in the Green River transformed the region and its farmers. The first settlers were Revolutionary War veterans from Virginia who received land claims for their military service. Most settlers served as privates in the war, received two hundred acres of land south of Kentucky's Green River, and migrated to the region with their families. In these early years, the Green River remained home to

\footnotetext{
${ }^{1}$ See Eugene D. Genovese, The Political Economy of Slavery: Studies in the Economy and Society of the Slave South, $2^{\text {nd }}$ ed. (1965; Hanover, N.H.: Wesleyan, 1989); and "Yeomen Farmers in a Slaveholders' Democracy," Agricultural History 2 (Apr. 1975). Also see Steve Hahn, The Roots of Southern Populism: Yeoman Farmers and the Transformation of the Georgia Upcountry, 1850-1890 (New York: Oxford University Press, 2006).

${ }^{2}$ See Daniel Vickers, "Competency and Competition: Economic Culture in Early America," The William and Mary Quarterly, $3^{\text {rd }}$ Series, 47 (Jan. 1990); and James Oakes, The Ruling Race: A History of American Slaveholders (New York: W. W. Norton \& Company, 1998).
} 
several Native American communities that resented settlers encroaching on their land. Raids on incoming settlers made the move to Kentucky dangerous. Instead of risking their lives, some veterans sold their claims to individuals or companies speculating in land. Despite the dangers, the temptation of unclaimed land attracted many settlers, who cleared small lots and planted crops. But confrontations arose between squatters who settled on the land and speculators who wanted to purchase and resell unclaimed tracts. In 1795, the Kentucky legislature sided with Green River squatters and allowed them to purchase two hundred acres of land on generous terms. Veterans' military claims and favorable legislation enabled yeomen to dominate the region. By the $1800 \mathrm{~s}$, most farms in the Green River were less than two hundred acres and gave the region its reputation as a good "poor man's country" where small farmers could acquire land.

The predominance of small farmers in the region shaped the Green River's early political development. Settlers supported the Democrats who promised to protect their access to land and fought banking legislation. Felix Grundy represented small farmers' interests and his "Green River Band" successfully challenged Bluegrass politicians. By logrolling for support, Grundy and his allies won several political concessions for small farmers, including debt relief, extended court systems, and credit extensions to pay their land debts. But 1805 marked a turning point for Green River Democrats. Henry Clay outmaneuvered Grundy and split his faction by proposing a bill that forced Green River farmers to pay their land debts immediately. Forced to choose between land or banking legislation, the Green River Band abandoned their anti-banking stance. The move undermined Grundy and the Democrats' political credibility and the party lost support in the region. Further economic development transformed the region's politics and the 
Green River began to resemble the Bluegrass. The region's merchants lobbied their local governments to increase access to markets by improving the region's two major riversthe Barren and Green - and making flatboat navigation possible.

The creation of the Kentucky Insurance Company in 1805 also shaped the Green River's political and economic development. Though the bank's capital was mostly expended in the Bluegrass, it gave local elites and merchants the impetus to expand the transportation infrastructure. Local elites and merchants lobbied county governments to expand commerce by improving market access. Despite the ability of banks to galvanize business and expand commercial opportunities, they did little to support small farmers directly. In 1807, the Bank of Kentucky opened a branch in Russellville. It had a marginal effect. The bank advertised lower interest rates for farmers taking out loans to purchase land, but most avoided the institution in its first years of operation. The bank also did little to promote or diversify manufacturing. Lack of business from farmers prevented the bank from operating at full capacity and with little specie on hand bank directors considered investing in manufacturing too risky. Green River politicians, however, supported banking and voted for legislation to create more institutions. In 1818, they helped to charter forty-two independent banks, including eleven in the Green River. These banks fared even worse. Having little secure capital, their bank notes declined in value and left farmers scrambling for ways to get rid of it.

In the $1820 \mathrm{~s}$, merchants again clamored for additional improvements to the region's waterways. Businessman James Rumsey Skiles led the movement and obtained a charter for the Green and Barren River Navigation Company. Steamboat navigation, Skiles and his allies argued, would make the Green River economically competitive with 
other parts of the state by increasing commercial access and reducing transportation costs. To demonstrate that steamboats could successfully navigate the rivers, Skiles arranged for a steamboat to travel up the Barren River and dock outside of Bowling Green. With financial aid from local and state governments, the company widened the rivers for steamboat traffic.

Small farmers' transition to the market production of staple crops was accompanied by an increasing reliance on slave labor. Enslaved populations doubled in most Green River counties between 1810 and 1820 . Evidence suggests slave labor was not concentrated in the hands of wealthy planters, but distributed more equally among small farmers than in other regions of Kentucky. Access to slave labor encouraged Green River farmers to produce staple crops for market. Skiles's Green and Barren River Navigation Company further integrated small farmers into the market economy. The company cleared the rivers, enabling flatboats to ply them. Farmers eagerly responded to increased commercial access. They built flatboats to transport their surplus crops to New Orleans, the largest market in the South. Those farmers who lived too far inland from the river relied on neighboring planters to purchase their goods and market it. Surplus crops like corn or tobacco were the most common marketable goods, but farmers also produced livestock such as pigs, cattle, and sheep. By the 1830s and 1840s, Kentucky's Green River produced among of the largest quantities of tobacco in the South.

Economic changes altered the Green River's political landscape. Small farmers' integration into the market economy benefitted politicians who supported internal improvements. By the 1830s, Kentucky Whigs under Clay's leadership dominated the state's political life. The Whig policy of protecting producers by raising tariffs appealed 
to Green River voters and the region solidly supported the party. Whigs in the state government supported the Green and Barren River Company and enabled it to expand in the 1830s. Skiles proposed an ambitious project to construct a series of locks and dams that allowed steamboats to dock at Bowling Green. Construction was slow and tensions arose between Skiles and the state board of internal improvements as the project's expenditures mounted. In 1837, when the state lacked the finances, the Bank of Kentucky provided a two hundred thousand dollar loan to continue the project. Internal improvements encouraged small farmers' market participation, but the usefulness of the improvements was short lived. Repairs and maintenance defrayed income earned from the five tollbooths.

While Kentucky's unique position as a border state warrants special scholarly attention, this study seeks to understand the economic behavior of small farmers in the South. Antebellum yeomen farmers were not passive participants in the market economy, but they played a crucial role in the economic development of their region. The thesis corrects earlier scholars' over-simplification of yeomen's economic behavior while challenging new scholarship to re-examine the historical sources. By bringing the same focus to ordinary farmers as to planters and slaves, historians will, as Eugene Genovese once noted, come to a fuller realization of the rise and fall of slavery in the South. ${ }^{3}$

\footnotetext{
${ }^{3}$ Genovese, "Yeomen Farmers," 342.
} 


\section{REFERENCES}

\section{PRIMARY SOURCES}

\section{FILSON HISTORICAL SOCIETY, LOUISVILLE, KENTUCKY}

Reverend William Adams Letter

Beall-Booth Family Papers

Beall-Pottenger Letters

Don Carlos Buell Papers

Nicholas Gautier Letter

Willis Green Papers

Joseph Hornsby Diary

John Shaw Letter

Whig Letter

William W. Walker Family Papers

KENTUCKY LIBRARY, WESTERN KENTUCKY UNIVERSITY, BOWLING GREEN, KENTUCKY

Alexander Collection

Ashcroft Family Papers

Billingsley Letter

David Barrow Journal

Chism Family Papers 
Henry Clay Letters

Claybrook Family Papers

Robert E. Craddock Family Papers

Coleman Family Papers

Drake Family Papers

Dunn Family Correspondence

Frazier Papers

William Frogett Land Deed

Goodman Family Papers

Goodnight Family Papers

Green County Records

Green River Research Collection

Helm Letters

Hines Family Collection

Loving Letter

Lucas Collection

McClanahan Family Papers

Andrew McFaddin Land Deed

McReynolds Family Papers

Melton Family Papers

Mills Letter

Josiah Newman Receipt

O'Hara Records 
Parker Family Papers

Payne Collection

Phelps Family Papers

Emeline Richmond Journal

Rowan Family Papers

Samuel Seay Journal

Thomas Shannon Journal

Slaughter Family Papers

South Union Shakers Collection

Strange Collection

Taliaferro Collection

Temple Collection

Underwood Collection

Walker Letter

Warren County Wills

Whig Pamphlet

Young Family Papers

\section{NEWSPAPERS}

[Frankfort] The Kentucky Gazette, Apr. 21, 1792 - Jan. 30, 1806

[Frankfort] The Kentucky Journal, Dec. 5, 1795

[Danville] The Mirror, Sept. 3, 1804 - Oct. 24, 1804

[Russellville] The Mirror, Nov. 1, 1806 - Dec. 1, 1807

[Philadelphia] The Pennsylvania Packet, Jan. 1, 1782 - Dec. 31, 1785 
[Danville] The People's Friend, Jan. 30, 1819

[Bowling Green] The Spirit of the Times, Dec. 16, 1826 - Feb. 17, 1827

[Russellville] The Weekly Messenger, Feb. 23, 1819 - Dec. 19, 1820.

[Lexington] The Western Monitor, Aug. 3, 1814 - Dec. 20, 1817

\section{SECONDARY SOURCES}

Adams, Donald R. "The Role of Banks in the Economic Development of the Old West," Essays in Nineteenth Century Economic History: The Old Northwest, eds. David C. Klingaman and Richard K. Vedder, Athens, Ohio: Ohio University Press, $1975,208-45$.

Aron, Stephen. How the West Was Lost: The Transformation of Kentucky from Daniel Boone to Henry Clay. Baltimore: The Johns Hopkins University Press, 1996.

Aron, Stephen. "Pioneers and Profiteers: Land Speculation and the Homestead Ethic in Frontier Kentucky," The Western Historic Quarterly 23 (May 1992), 179-98.

Billington, Louis and David Brown. "Yeomen and Yankees Across the Mason-Dixon Line: A Different Perspective on the Antebellum North/South Divide?" European Contributions to American Studies 58 (Aug. 2004), 101-116.

Boles, John B. A Companion to the American South. Malden, MA: Blackwell Publishing, 2004.

Brown, Kathleen M. Good Wives, Nasty Wenches, and Anxious Patriarchs: Gender Race and Power in Colonial Virginia. Chapel Hill, NC: The University of North Carolina Press, 1996.

Burns, Rex. Success in America: The Yeoman Dream and the Industrial Revolution. Amherst: University of Massachusetts Press, 1976.

Cash, W. J. The Mind of the South. 1940; New York: Vintage Books, 1969.

Clark, Christopher. "Household Economy, Market Exchange and the Rise of Capitalism in the Connecticut Valley, 1800-1860," Journal of Social History 2 (Winter, 1979), 169-189.

Connelley, William E. and E. Merton Coulter. History of Kentucky. 2 vols. New York: The American Historical Society, 1922.

Cooper, William J. Jr. "Daniel Interpreter of the Antebellum South,” in Social Relations 
in the Old South. Baton Rouge: Louisiana State University Press, 1979.

Crocker, Helen Barter. "Steamboats for Bowling Green," The Filson Club History Quarterly 46 (1972), 9-23.

Crocker, Helen Barter. The Green River of Kentucky. Lexington: The University Press of Kentucky, 1976.

Crothers, A. Glenn. "Banks and Economic Development in Post-Revolutionary Northern Virginia, 1790-1812," The Business History Review 73 (Spring 1999), 1-39.

Dodd, William E. The Cotton Kingdom: A Chronicle of the Old South. Baton Rouge: Louisiana State University Press, 1921.

Duke, Basil W. History of the Bank of Kentucky 1792-1895. 1895; New York: Arno Press, 1980.

Ekirch, A. Roger. "'A New Government of Liberty': Hermon Husband's Vision of Backcountry North Carolina, 1755," The William and Mary Quarterly, 3rd Series, 34 (Oct. 1977), 632-46.

Fogel, Robert L. and Stanley L. Engerman, Time on the Cross: The Economics of American Negro Slavery. Boston: Little, Brown, and Company, 1974.

Friend, Craig T. "Merchants and Markethouses: Reflections on Moral Economy in Early Kentucky," Journal of the Early Republic 17 (Winter 1997), 553-74.

Gates, Paul W. "Tenants of the Log Cabin," Mississippi Valley Historical Review 49 (June 1962), 3-31.

Genovese, Eugene D. The Political Economy of Slavery: Studies in the Economy and Society of the Slave South, $2^{\text {nd }}$ ed. (1965; Hanover, N.H.: Wesleyan, 1989)

Genovese, Eugene D. "Yeomen Farmers in a Slaveholders' Democracy," Agricultural History 49 (Apr. 1975), 331-42.

Gray, Lewis C., History of Agriculture in the Southern United States to 1860, 2 vols. New York: Peter Smith, 1941.

Greenberg, Kenneth S., Masters and Statesmen: The Political Culture of American Slavery. Baltimore: John Hopkins University Press Ltd, 1985.

Hahn, Steven. The Roots of Southern Populism: Yeomen Farmers and the Transformation of the Georgia Upcountry, 1850-1890. New York: Oxford University Press, 2006. 
Harris, J. William. Plain Folk and Gentry in a Slave Society: White Liberty and Black Slavery in Augusta's Hinterlands. Baton Rouge: Louisiana State University Press, 1985.

Harrison, Lowell H. and James C. Klotter. A New History of Kentucky. Lexington, Kentucky: The University of Kentucky Press, 1997.

Henderson, Archibald. "Richard Henderson and the Occupation of Kentucky, 1775" The Mississippi Valley Historical Review 1 (Dec. 1914), 341-63.

Henretta, James A. "Families and Farms: Mentalite in Pre-Industrial America," The William and Mary Quarterly, 3rd Series, 35, (Jan. 1978), 3-32.

Hundley, Daniel R. Social Relations in our Southern States. New York: H. B. Price, 1860.

Hyde, Samuel C. Jr. Plain Folk of the South Revisited. Baton Rouge: Louisiana State University Press, 1997.

Hyde, Samuel C. Jr. "Plain Folk Yeomanry in the Antebellum South," in $A$ Companion to the American South, ed. John B. Boles, Malden, MA: Blackwell, 2002.

Jefferson, Thomas. Notes on the State of Virginia. Richmond: J. W. Randolph, 1853.

Kulikoff, Allan. "The Transition to Capitalism in Early America," $3^{\text {rd }}$ Series, 46 (Jan. 1989), 120-44.

Larkin, Jack. "The View from New England: Notes on Everyday Life in Rural America to 1850," American Quarterly, 34 (1982), 244-61.

Lucas, Marion B. A History of Blacks In Kentucky, Volume 1: From Slavery to Segregation, 1760-1891. Frankfort, Kentucky: The Kentucky Historical Society, 1992.

Majewski, John. "Who Financed the Transportation Revolution? Regional Divergence and Internal Improvements in Antebellum Pennsylvania and Virginia," The Journal of Economic History 56 (Dec. 1996), 763-88.

McCurry, Stephanie. Masters of Small Worlds: Yeoman Households, Gender Relations, and the Political Culture of the Antebellum South Carolina Low Country. New York: Oxford University Press, 1995.

Mitchell, Robert. Commercialism and Frontier: Perspectives on the early Shenandoah Valley. Charlottesville: University Press of Virginia, 1977. 
Olmstead, Frederick L., A Journey in the Back Country. 1860; New York: Shocken, 1970.

Owsley, Frank L. Plain Folk of the Old South. 1949; Baton Rouge: Louisiana State University Press, 2008.

Paine, Christopher. "Kentucky Will be the Last to Give Up the Union," (Ph.D. Diss., University of Kentucky, 1998).

Parks, Joseph Howard. Felix Grundy, Champion of Democracy. Baton Rouge: Louisiana State University, 1940.

Parr, Elizabeth. "Kentucky's Overland Trade with the Antebellum South," Filson Club Historical Quarterly 2 (Jan. 1928), 71-81.

Perkins, Elizabeth A. "The Consumption Frontier: Household Consumption in Early Kentucky," Journal of American History 78 (Sept. 1991), 486-510.

Phillips, Ulrich Bonnell. Life and Labor in the Old South. 1929; Boston: Little \& Brown, 1963.

Priest, Nancy L. "Joseph Rogers Underwood: Nineteenth Century Kentucky Orator," Register of the Kentucky Historical Society 75 (Oct. 1977), 286-303.

Ramage, James A. "The Green River Pioneers: Squatters, Soldiers, and Speculators," Register of the Kentucky Historical Society 75 (July 1977), 171-90.

Robbins, M. "Pre-emption-A Frontier Triumph," The Mississippi Valley Historical Review 18 (Dec. 1931), 331-49.

Rockoff, Hugh T. "Varieties of Banking and Regional Economic Development in the United States, 1840-1860," Journal of Economic History 35 (Mar. 1975), 160181.

Royalty, Dale Maurice. "Banking, Politics, and the Commonwealth, Kentucky, 18001825" (Ph.D. diss., University of Kentucky, 1972).

Rhorer, Mark A. "Believers In Dixie: A Cultural Geography of the Kentucky Shakers" (Ph.D. Diss., Florida Atlantic University, 2007).

Sarson, Steven. "Yeoman Farmers in a Planters' Republic: Socioeconomic Conditions and Relations in Early National Prince George's County, Maryland," Journal of the Early Republic 1 (Spring 2009), 63-99. 
Sellers, Jr., Charles Grier. "Who Were the Southern Whigs?" The American Historical Review 59, (Jan. 1954), 335-46.

Sherrod, Ricky L. "Plain Folk, Planters, and the Complexities of Southern Society, Kinship Ties, in Nineteenth-Century Northwest Louisiana and Northeast Texas," Southwestern Historical Quarterly 1 (July 2009), 1-31.

Sokoloff, Kenneth L. and Stanley L. Engerman, "History Lessons: Institutions, Factor Endowments, and Paths of Development in the New World," The Journal of Economic Perspectives 14 (Summer 2000), 217-32.

Tallant, Harold D. Evil Necessity: Slavery and Political Culture in Antebellum Kentucky (Lexington, Kentucky: The University Press of Kentucky, 2003).

Teute, Fredrika Johanna. "Land, Liberty, and Labor in the Post-Revolutionary Era: Kentucky as the Promised Land" (Ph.D diss., The John Hopkins University, 1988).

University of Virginia. Online Census Statistics. <http://mapserver.lib.virginia.edu >

Van Atta, John R. "Western Lands and the Political Economy of Henry Clay's American System, 1819-1832," Journal of the Early Republic, 21 (Winter 2001), 633-65.

Vickers, Daniel. "Competency and Competition: Economic Culture in Early America." William and Mary Quarterly, 3rd Series, 47 (January 1990), 3-29.

Watlington, Patricia Sue. "The Kentucky Spirit: Kentucky Politics, 1779-92" (Ph.D. diss., Yale University, 1964).

Wermuth, Thomas S. "'To Market, To Market': Yeoman Farmers, Merchant Capitalists and the Development of Capitalism in the Hudson River Valley, 1760-1820," Essays in Economic and Business History 9 (Mar. 1991), 20-34.

Wetherington, Mark V. Plain Folk's Fight: The Civil War and Reconstruction in Piney Woods Georgia. Chapel Hill, NC: The University of North Carolina Press, 2005.

Wetherington, Mark V. The New South Comes to Wiregrass Georgia, 1860-1910. Knoxville: University of Tennessee Press, 1994.

Wood, Walter Kirk. "Before Republicanism: Frank Lawrence Owsley and the Search for Southern Identity, 1865-1965," Southern Studies: An Interdisciplinary Journal of the South 6 (Oct. 1995), 65-77.

Wright, Gavin. The Political Economy of the Cotton South. New York: Norton Press, 1978. 
Wright, Robert E. "Banking and Politics in New York, 1784-1829" (Ph.D. diss., State University of New York at Buffalo, 1997).

Wright, Robert E. "Corporations and the Economic Growth and Development of the Antebellum Ohio River Valley," Ohio Valley History 9 (Winter 2009), 48-70.

\section{ONLINE SOURCES}

Barren County, Kentucky, Online Archives

$<\mathrm{http} / /$ www.barrencoky.com/records/records.html $>$.

United States Census Office Online Archives, $<$ http://www.agcensus.usda.gov/Publications/Historical_Publications/index.asp $>$.

University of Virginia's Online Census Survey, $<$ http://mapserver.lib.virginia.edu $>$. 
Appendix

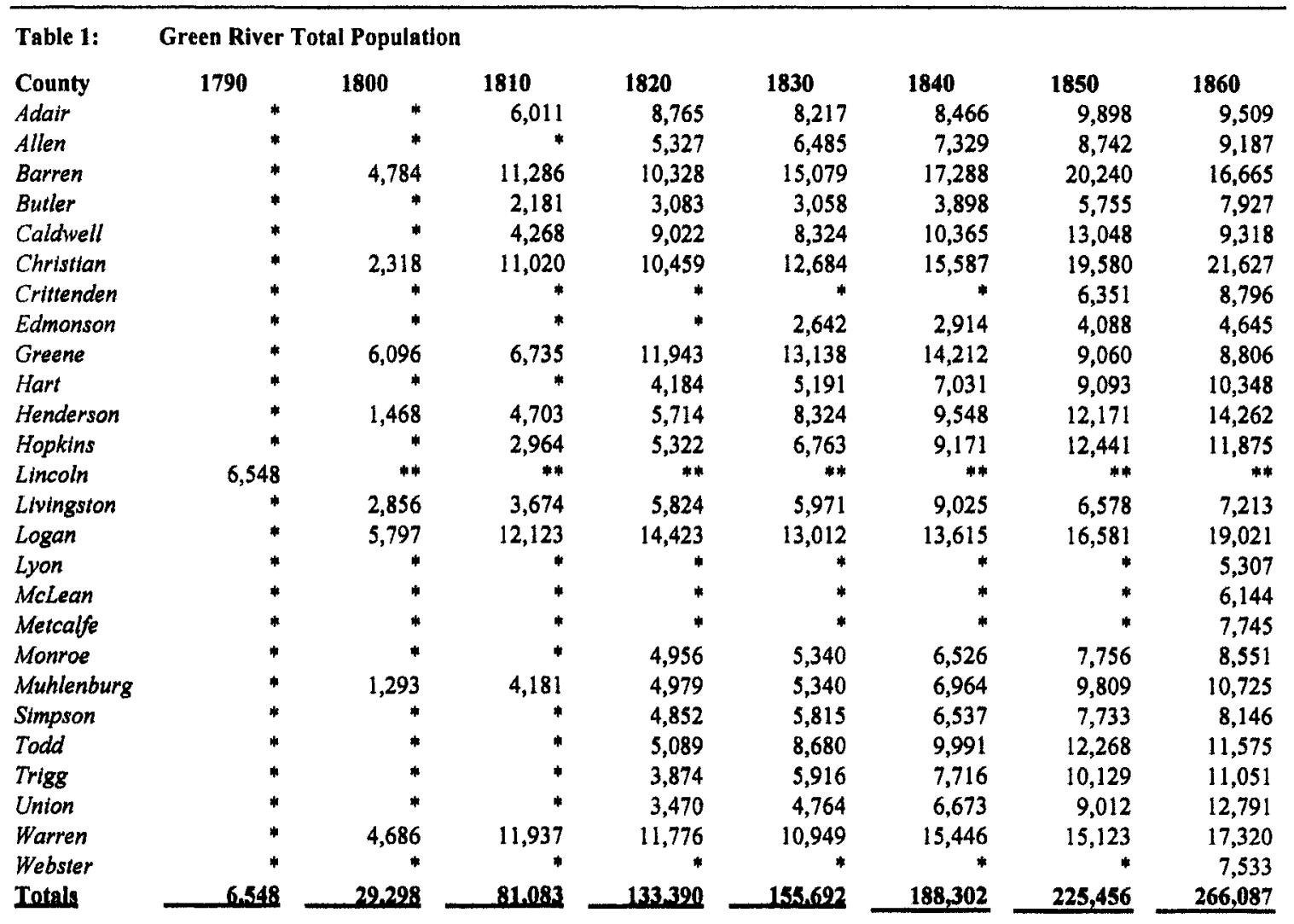

* indicates county was not yet formed

** indicates county no longer included in the Green River 


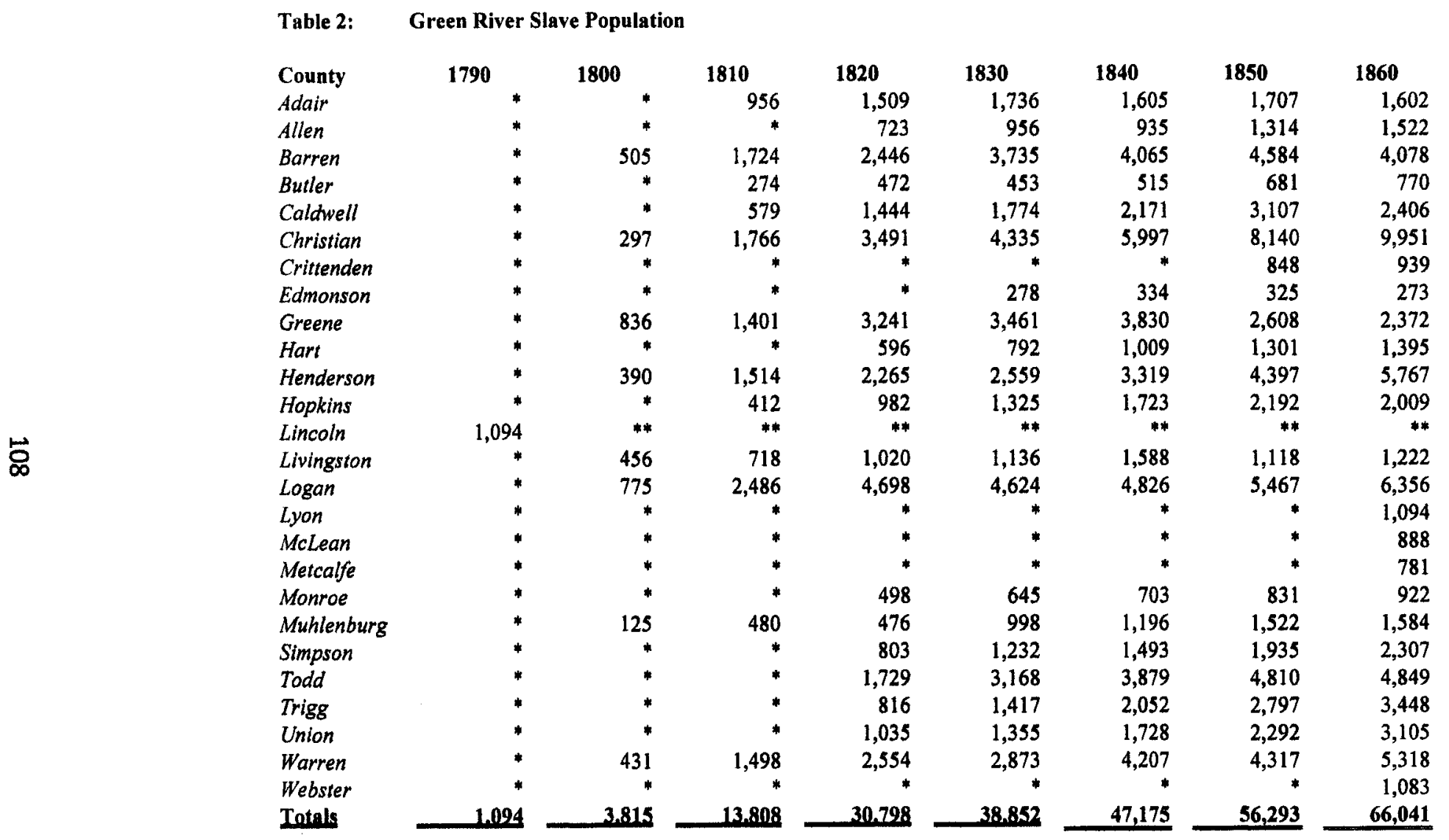

* indicates county was not yet formed

** indicates county no longer included in the Green River 
Table 3: Green River Livestock Production

\begin{tabular}{|c|c|c|c|c|c|c|c|c|c|}
\hline \multirow[b]{2}{*}{ County } & \multicolumn{3}{|c|}{ Cattle } & \multicolumn{3}{|c|}{ Sheep } & \multicolumn{3}{|c|}{ Swine } \\
\hline & 1840 & 1850 & 1860 & 1840 & 1850 & 1860 & 1840 & 1850 & 1860 \\
\hline Adair & 9,018 & 5,269 & 2,696 & 12,263 & 15,968 & 9,406 & 31,192 & 41,886 & 17,574 \\
\hline Allen & 8,651 & 2,985 & 2,598 & 11,419 & 10,638 & 9,399 & 28,165 & 29,823 & 18,459 \\
\hline Barren & 18,472 & 7,419 & 6,224 & 24,914 & 23,923 & 18,507 & 68,932 & 65,710 & 32,418 \\
\hline Butler & 5,784 & 3,113 & 3,275 & 4,978 & 4,357 & 7,292 & 21,561 & 23,797 & 13,669 \\
\hline Caldwell & 11,191 & 3,823 & 4,030 & 18,815 & 10,767 & 7,257 & 33,189 & 54,135 & 25,157 \\
\hline Christian & 15,953 & 6,424 & 6,022 & 18,916 & 19,584 & 15,915 & 52,656 & 61,961 & 47,202 \\
\hline Crittenden &  & 2,767 & 3,939 & * & 6,485 & 8,951 & $*$ & 25,466 & 21,121 \\
\hline Edmonson & 2,178 & 2,427 & 1,879 & 3,131 & 4,955 & 5,307 & 7,428 & 17,907 & 9,388 \\
\hline Greene & 11,642 & 4,880 & 3,409 & 18,149 & 12,825 & 9,502 & 46,691 & 29,571 & 17,522 \\
\hline Hart & 5,599 & 4,922 & 2,343 & 6,816 & 10,807 & 9,408 & 9,933 & 27,127 & 20,007 \\
\hline Henderson & 9,206 & 5,740 & 6,159 & 6,561 & 9,235 & 6,159 & 31,383 & 46,734 & 36,142 \\
\hline Hopkins & 9,984 & 5,127 & 6,115 & 8,992 & 16,131 & 18,845 & 32,552 & 53,314 & 30,146 \\
\hline Livingston & 9,284 & 2,550 & 2,438 & 7,623 & 4,208 & 5,331 & 29,035 & 19,730 & 15,256 \\
\hline Logan & 3,619 & 6,221 & 4,519 & 4,821 & 19,353 & 16,120 & 11,878 & 55,858 & 40,826 \\
\hline Lyon & * & $*$ & 2,239 & * & $*$ & 3,326 & $*$ & * & 11,398 \\
\hline McLean & * & * & 2,144 & $*$ & * & 4,149 & * & $*$ & 5,567 \\
\hline Metcalfe & $*$ & $*$ & 2,518 & $*$ & * & 7,798 & * & $*$ & 11,374 \\
\hline Monroe & 5,314 & 2,330 & 3,264 & 8,952 & 8,248 & 10,144 & 29,396 & 30,507 & 14,375 \\
\hline Muhlenburg & 8,865 & 4,576 & 5,179 & 7,946 & 11,630 & 9,235 & 32,959 & 37,862 & 20,573 \\
\hline Simpson & 4,948 & 2,667 & 3,047 & 8,088 & 8,668 & 7,913 & 14,134 & 26,521 & 21,577 \\
\hline Todd & 8,359 & 5,180 & 3,639 & 11,557 & 14,596 & 9,097 & 33,465 & 44,569 & 27,870 \\
\hline Trigg & 7,993 & 2,957 & 3,465 & 8,134 & 7,755 & 6,814 & 30,115 & 31,303 & 21,273 \\
\hline Union & 7,059 & 5,409 & 7,483 & 6,392 & 8,914 & 10,116 & 26,209 & 38,177 & 39,865 \\
\hline Warren & 34,523 & 8,535 & 7,599 & 21,729 & 18,842 & 19,375 & 52,329 & 54,135 & 40,253 \\
\hline Webster & * & $*$ & 2,912 & * & * & 5,324 & 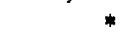 & * & 18,549 \\
\hline Totals & 197.642 & 95.321 & 99.135 & 220.196 & 247.889 & 240.690 & 623.202 & 816,093 & 577.561 \\
\hline
\end{tabular}

* indicates county was not yet formed

Source: United States Department of Agriculture Agricultural Census <http://www.agcensus.usda.gov/Publications/Historical_Publications/index.asp>. 
Table 4: Green River Crop Production

\begin{tabular}{|c|c|c|c|c|c|c|c|c|c|c|c|c|}
\hline \multirow[b]{2}{*}{ County } & \multicolumn{3}{|c|}{ Wheat (in bushels) } & \multicolumn{3}{|c|}{ Oats (in bushels) } & \multicolumn{3}{|c|}{ Corn (in bushels) } & \multicolumn{3}{|c|}{ Tobacco (in pounds) } \\
\hline & 1840 & 1850 & 1860 & 1840 & 1850 & 1860 & 1840 & 1850 & 1860 & 1840 & 1850 & 1860 \\
\hline Adair & 27,888 & 15,938 & 29,513 & 194,647 & 80,536 & 24,195 & 308,103 & 537,945 & 413,295 & $1,938,116$ & 509,003 & 767,393 \\
\hline Allen & 47,157 & 9,563 & 29,248 & 193,418 & 65,206 & 32,109 & 312,665 & 411,655 & 450,228 & 598,870 & 760,806 & 977,491 \\
\hline Barren & 80,346 & 37,097 & 94,763 & 229,403 & 208,393 & 66,732 & 697,528 & $1,007,560$ & $1,146,696$ & $2,321,288$ & $2,155,551$ & $2,239,002$ \\
\hline Butler & 15,313 & 4,058 & 22,983 & 35,424 & 40,840 & 6,469 & 183,088 & 289,774 & 310,080 & 170,776 & 207,819 & 984,237 \\
\hline Caldwell & 53,165 & 8,574 & 45,693 & 191,637 & 89,557 & 10,978 & 601,265 & 767,725 & 691,525 & $2,367,625$ & $1,435,479$ & $3,467,871$ \\
\hline Christian & 103,833 & 45,678 & 205,413 & 298,585 & 329,152 & 62,241 & $1,022,850$ & $1,235,290$ & $1,155,851$ & $3,409,502$ & $6,312,076$ & $11,409,016$ \\
\hline Crittenden & * & 5,759 & 38,251 & * & 45,460 & 3,999 & * & 386,705 & 528,950 & * & 505,637 & $1,845,790$ \\
\hline Edmonson & 6,733 & 4,322 & 15,912 & 24,780 & 34,555 & 7,149 & 57,050 & 193,095 & 201,500 & 91,122 & 86,980 & 366,055 \\
\hline Greene & 75,221 & 19,870 & 31,101 & 143,860 & 114,111 & 25,498 & 338,664 & 505,757 & 504,000 & $1,916,711$ & $1,267,971$ & $1,558,697$ \\
\hline Hart & 21,869 & 14,763 & 45,331 & 64,209 & 88,550 & 15,555 & 144,722 & 434,613 & 480,214 & 346,824 & 814,444 & $1,653,382$ \\
\hline Henderson & 37,086 & 10,571 & 48,391 & 46,776 & 71,618 & 24,578 & 503,670 & 926,865 & $1,132,935$ & $2,977,810$ & $4,292,960$ & $7,938,836$ \\
\hline Hopkins & 41,595 & 14,325 & 31,215 & 58,452 & 61,901 & 10,784 & 424,595 & 741,032 & 668,392 & $1,716,555$ & $2,180,699$ & $3,104,330$ \\
\hline Livingston & 27,748 & 2,308 & 41,969 & 50,140 & 25,718 & 2,224 & 421,415 & 331,436 & 415,203 & $1,222,590$ & 41,200 & 822,522 \\
\hline Logan & 40,367 & 50,316 & 213,609 & 65,510 & 242,340 & 84,993 & 205,440 & $1,103,186$ & $1,114,063$ & 393,357 & $2,684,767$ & $3,926,818$ \\
\hline Lyon & * & " & 15,854 & * & * & 1,851 & * & " & 283,733 & * & • & $1,156,326$ \\
\hline McLean & " & " & 22,946 & " & * & 8,450 & * & * & 319,195 & * & * & $1,623,428$ \\
\hline Metcalfe & * & * & 24,434 & * & " & 32,024 & * & * & 305,645 & * & * & 772,901 \\
\hline Monroe & 33,676 & 12,443 & 26,467 & 77,028 & 77,151 & 21,575 & 311,047 & 384,705 & 344,451 & 420,012 & 692,762 & 667,362 \\
\hline Muhlenburg & 34,960 & 13,916 & 23,441 & 37,731 & 74,020 & 13,269 & 351,936 & 495,328 & 512,685 & 286,747 & 685,050 & $1,597,336$ \\
\hline Simpson & 45,590 & 19,914 & 51,972 & 106,333 & 145,855 & 51,188 & 281,756 & 516,158 & 594,955 & 708,131 & $1,221,314$ & $1,641,025$ \\
\hline Todd & 83,717 & 40,485 & 137,588 & 206,065 & 203,027 & 33,424 & 632,950 & 803,941 & 735,052 & $3,123,898$ & $3,739,685$ & $4,964,796$ \\
\hline Trigg & 37,172 & 11,149 & 31,911 & 93,270 & 87,090 & 13,660 & 499,255 & 604,515 & 553,033 & $1,879,537$ & $1,653,485$ & $3,776,688$ \\
\hline Union & 33,624 & 11,994 & 109,218 & 38,441 & 50,045 & 14,129 & 495,595 & 680,640 & $1,132,900$ & 612,158 & 494,784 & $2,051,000$ \\
\hline Warren & 80,180 & 33,473 & 115,619 & 183,240 & 198,600 & 83,329 & 715,566 & $1,031,545$ & $1,176,471$ & $1,629,890$ & $1,401,751$ & $2,753,473$ \\
\hline Webster & & & 19,618 & " & " & 9,022 & & * & 432,446 & * & * & $2,455,245$ \\
\hline Totals & 927.240 & 386.516 & 1.472 .460 & 2.175 .702 & 2.333 .725 & 661.423 & 8.509 .160 & $13,389,470$ & $15,603,498$ & 28.331 .719 & 33.144 .223 & 64.521 .020 \\
\hline
\end{tabular}

* indicates county was not yet formed

Source: United States Department of Agriculture Agricultural Census <http://www,agcensus, usda.gov/Publications/Historical_Publications/index.asp>. 


\section{CURRICULUM VITAE}

NAME: $\quad$ Christopher Patrick Petzold

ADDRESS: $\quad 303$ Saint Andrews Way

Shepherdsville, KY 40165

DOB: $\quad$ Louisville, KY - November 11, 1982

EDUCATION

\& TRAINING: $\quad$ B.A., History

University of Louisville

2001-2006

PROFESSIONAL SOCIETIES: Phi Alpha Theta

INVITED PRESENTATIONS: “I Have Exterminated Them All": The French Republic's Response to the Vendée Counterrevolution, 1793-1794, and a comparative study of the Bosnian and Darfur genocides' presented at the "Whose Land is This?" Civil Conflicts and Civil Identities Conference, University of Missouri Columbia April 12, 2008 